Article

\title{
The Relationship between the Expression of Fatty Acyl Desaturase 2 (fads2) Gene in Peripheral Blood Cells (PBCs) and Liver in Gilthead Seabream, Sparus aurata Broodstock Fed a Low n-3 LC-PUFA Diet
}

\author{
Shajahan Ferosekhan ${ }^{1,2, *(\mathbb{D})}$, Serhat Turkmen ${ }^{1,3}{ }^{\mathbb{D}}$, Hanlin Xu ${ }^{1}$, Juan Manuel Afonso ${ }^{1}$, \\ Maria Jesus Zamorano ${ }^{1}$, Sadasivam Kaushik ${ }^{1}{ }^{\mathbb{D}}$ and Marisol Izquierdo ${ }^{1}$ \\ 1 Aquaculture Research Group (GIA), IU-ECOAQUA, Universidad de Las Palmas de Gran Canaria, \\ 35214 Telde, Spain; turkmen@uab.edu (S.T.); hanlinxuulpgc@outlook.com (H.X.); \\ juanmanuel.afonso@ulpgc.es (J.M.A.); mariajesus.zamorano@ulpgc.es (M.J.Z.); \\ sachi.kaushik@ulpgc.es (S.K.); marisol.izquierdo@ulpgc.es (M.I.) \\ 2 ICAR-Central Institute of Freshwater Aquaculture, Bhubaneswar 751002, India \\ 3 Department of Biology, University of Alabama at Birmingham, Birmingham, AL 35294, USA \\ * Correspondence: feroseaqua@gmail.com
}

Received: 21 May 2020; Accepted: 17 July 2020; Published: 19 July 2020

\begin{abstract}
The principle aim of this study is to elucidate the relationship between the fatty acid desaturase 2 gene (fads2) expression pattern in peripheral blood cells (PBCs) and liver of gilthead seabream (GSB), Sparus aurata broodstock in order to determine the possible use of fads2 expression as a potential biomarker for the selection of broodstock. This selection could be utilized for breeding programs aiming to improve reproduction, health, and nutritional status. Passive Integrated Transponder (PIT)-tagged GSB broodstock (Male-1.22 $\pm 0.20 \mathrm{~kg} ; 44.8 \pm 2 \mathrm{~cm}$ and female-2.36 \pm $0.64 \mathrm{~kg} ; 55.1 \mathrm{~cm}$ ) were fed a diet containing low levels of fish meal and fish oil (EPA 2.5; DHA 1.7 and n-3 LC-PUFA 4.6\% TFA) for one month. After the feeding period, fads2 expression in PBCs and liver of both male and female broodstock were highly significantly correlated $(\mathrm{r}=0.89 ; p<0.001)$. Additionally, in male broodstock, liver fads2 expression was significantly correlated $(p<0.05)$ to liver contents in $16: 0(\mathrm{r}=0.95 ; p=0.04)$ and total saturates $(\mathrm{r}=0.97 ; p=0.03)$ as well as to $20: 3 \mathrm{n}-6 / 20: 2 \mathrm{n}-6$ $(\mathrm{r}=0.98 ; p=0.02)$ a Fads2 product/precursor ratio. Overall, we found a positive and significant correlation between fads2 expression levels in the PBCs and liver of GSB broodstock. PBCs fads2 expression levels indicate a strong potential for utilization as a non-invasive method to select animals having increased fatty acid bioconversion capability, better able to deal with diets free of fish meal and fish oil.
\end{abstract}

Keywords: biomarker; broodstock; fatty acyl desaturase (fads2); fatty acid; lipid metabolism

\section{Introduction}

The ability of teleosts to biosynthesize long-chain ( $\geq$ C20) polyunsaturated fatty acids (LC-PUFA), such as arachidonic acid (ARA, 20:4n-6), eicosapentaenoic acid (EPA, 20:5n-3) or docosahexaenoic acid (DHA, 22:6n-3), from 18 carbon PUFA substrate, linoleic acid (LA; 18:2n-6), and $\alpha$-linolenic acid (ALA; $18: 3 n-3)$ is limited [1-3]. Knowledge on this is of vital importance in order to quantify the dietary requirements for essential fatty acids (EFA) in farmed fish and to tailor the fatty acid composition of the fish fillet for human consumption [4,5]. The fatty acid biosynthesis comprises several steps catalyzed by fatty acyl desaturases (Fads1- $\Delta 5$ and Fads2- $\Delta 6$ desaturase) and an elongation of very 
long chain fatty acids proteins (Elovl), where $\Delta 6$ desaturase is a major rate-limiting step in the fatty acid biosynthesis pathway (Figure 1) [3,6]. The $\Delta 6$ desaturase introduces new double bonds into fatty acyl chains, essential to the first step in the LC-PUFA biosynthesis and is encoded by the fatty acyl desaturase gene ( $f a d s)$. Carnivorous species such as felids have very limited ability to synthesize LC-PUFA [7], as well as teleost fish from higher trophic levels, which consequently have a dietary requirement for pre-formed LC-PUFA [8]. In general, the majority of vertebrates lack the capacity to biosynthesize PUFA de novo, and different teleost species have a wide range of bioconversion capability for converting dietary C18 PUFA to LC-PUFA [1,8,9]. Among teleosts, freshwater fish and especially fish from lower trophic levels are considered capable of bioconversion of dietary C18 PUFA such as linoleic acid (LA; 18:2n-6) and $\alpha$-linolenic acid (ALA; 18:3n-3) into LC-PUFA, whereas marine teleosts have limited ability to biosynthesize the LC-PUFA from LA and ALA substrates $[1,8,10]$. This is imputed to the lower activity of Fads, which is due to the lower expression of the fads gene in marine fish compared to freshwater fish [6,11-13]. Low expression or absence of the fads gene is the main reason for the reduced synthesis of LC-PUFA in marine fish $[6,8,14]$. Fads has been characterized and studied in several organisms from lower invertebrates to higher vertebrates [14]. Mammals possess two FADS enzymes termed FADS1 and FADS2, which are involved in different steps of desaturation activity. FADS1 is a $\triangle 5$ desaturase, whereas FADS2 is a $\Delta 6$ desaturase with the ability to utilize C18 substrates [15] in order to biosynthesize ARA, EPA, and DHA. In marine fish, it is well documented that the biosynthesise of n-3 LC-PUFA is initiated by the delta 6 fatty acid desaturase ( $\triangle 6$ Fads), which acts on ALA or LA to produce EPA and DHA or ARA through several steps of desaturation, elongation, and $\beta$-oxidation (Figure 1 ).

Fads2 from most of the teleost species show $\Delta 6$ desaturase activity; its activity was also identified in many species such as zebra fish, Danio rerio [16], gilthead seabream (GSB) (Sparus aurata) [1,17-20], European seabass (Dicentrarchus labrax) [21,22], black seabream (Acanthopagrus schlegeli) [23], meagre (Argyrosomus regius) [24], orange-spotted grouper (Epinephelus coioides) [25], nibe croaker (Nibea mitsukurii) [26], rabbit fish (Siganus canaliculatus) [27], rainbow trout (Oncorhynchus mykiss) [19], Atlantic salmon (Salmo salar) [2,28], and Atlantic cod (Gadus morhua) [29]. Analysis of the different studies on enzyme activities of several species shows that many species have several desaturase activities. For example, zebrafish $\Delta 6$ desaturase, which was the first functionally characterized Fads 2 in a teleost, showed three desaturase activities: $\Delta 5, \Delta 6$, and $\Delta 8$ [16]. Similarly, dual $\Delta 6$ and $\Delta 8$ desaturase activity has been reported in other teleost Fads2 including GSB [1,19], rabbitfish [1,8,27], rainbow trout [19], turbot [19], Atlantic salmon [1,2], and grouper [25]. The fads2 gene expression in different tissues has been studied in several marine fish species although the importance and implication of the fads2 gene in fish growth and reproduction has not been deeply studied besides a few studies by our own research group [30-33].

Lipid metabolism and fatty acid synthesis occurs mainly in the liver, then fatty acids are transported through the blood to the rest of the tissues in the body for utilization in diverse physiological functions [34]. Knowing the activity and expression of $\Delta 6$ desaturase and fads 2 in liver is paramount in order to ascertain FA's synthesis and mobilization to various tissues. The measurement of fads2 expression in the liver, however, requires sacrificing the animal and it is a major constraint for working on live fish. Hence, it is necessary to develop a non-invasive method to study the fads 2 expression in fish. It is well known that blood is the most accessible tissue to study the well-being of an animal to predict or assess the physiological conditions of other tissues by means of a non-invasive manner. In humans, peripheral blood cells (PBCs) are widely used to check the health status by analyzing the gene expression pattern in peripheral blood and to predict the same gene expression in non-accessible tissues like brain, liver, gonad, kidney, lungs etc. In various human studies, expression of many health status indicative genes in PBCs show significant correlations to the respective gene expression in different other organ tissues [35-38]. 


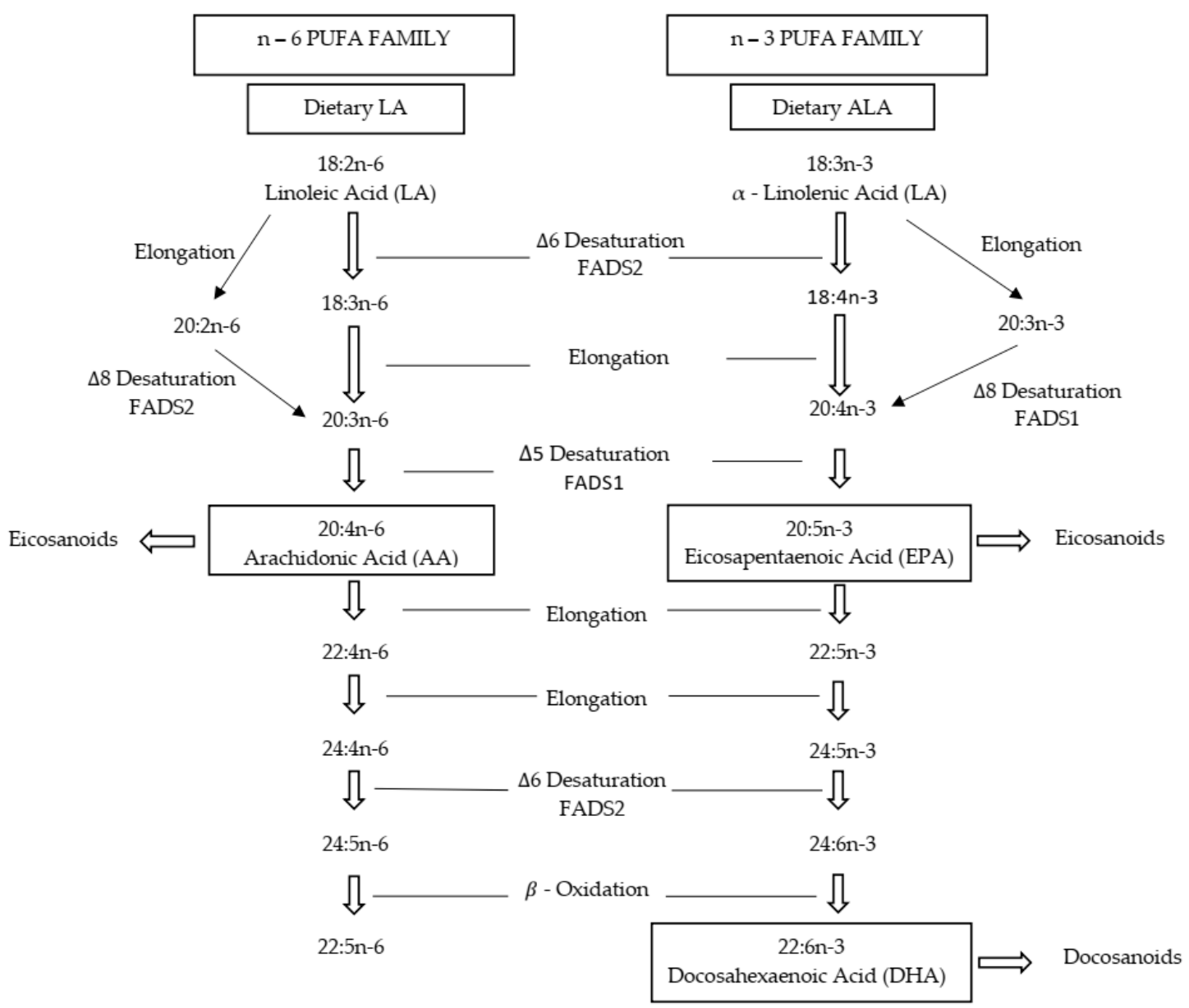

Figure 1. Endogenous biosynthesis pathway of n-6 and n-3 long chain polyunsaturated fatty acids (LC-PUFA) from linoleic acid (LA) and $\alpha$-linolenic acid (ALA) substrate through desaturation (Fads), elongation (Elvol), and $\beta$-oxidation in fish.

The presence of a nucleus and functional mitochondria in the red blood cells of fish makes blood a promising tissue to analyze the gene expression and metabolic responses in an integrative and non-invasive manner. Some studies with GSB have addressed the issue to determine whether samples collected without sacrificing animals provide a reliable measure of mitochondrial functioning and energy metabolism at the level of the whole organism [39]. In one such study using transcriptome analysis, it was observed that whole blood cell gene expression of hypoxia induced GSB juveniles and reflected the metabolic condition and mitochondrial respiration of target tissues [39]. Such an approach could be used in GSB broodstock to understand the relationship between fads2 expression in PBCs and the liver to identify the potential of using fads 2 as a biomarker to assess the role of n-3 LC-PUFA in reproductive performance. The correlation between PBCs and hepatic fads2 expression has not been studied so far in any fish or even in other animals. However, relative fads 2 expression between various tissues has been studied and reported in humans [40] as well as in some fish such as the Japanese seabass (Lateolabrax japonicus) or the golden pompano (Trachinotus ovatus) [41,42]. In Japanese seabass, fads2 expression was found to be higher in the brain, eyes, liver, and intestine compared to the kidney, skin, muscle, gill, spleen, stomach, blood, and heart [41]. In golden pompano, the fads2 expression level was higher in the brain, in comparison to the small intestine and the female gonads, whereas lower expression levels were observed in the fin, gill, blood, and kidney [42].

To our knowledge, there is no known information on the comparative relationship between blood and liver fads 2 expression patterns, nor potential differences in male and female fish. The blood fads 2 gene expression as a biomarker could be useful to study not only the fatty acid metabolism in fish but also to assess the nutritional quality of fish fillet $[32,33,43]$ or the reproductive performance in 
fish [31,33]. The fads2 expression pattern in animals are species- and sex-specific [44-47]. In an earlier study, we observed that fads2 expression in the blood of GSB broodstock was higher in females than in males [31] and that the GSB exhibits great variations in the fads2 expression among individuals. Therefore, the present study was undertaken to relate the expression pattern of PBCs and hepatic fads2 in fish to elucidate the relationship in GSB broodstock to identify the potential of selecting PBCs fads2 as a biomarker to understand the reproductive performance of fish. A second objective was to analyze the hepatic fatty acid profile of GSB broodstock fish exhibiting different fads2 expression levels in peripheral blood cells and liver.

\section{Materials and Methods}

\subsection{Broodstock Management and Feeding}

Gilthead seabream broodstock were individually PIT tagged (EID Iberica SA-TROVAN, Madrid, Spain) and maintained in a 10 ton square tank. Male $(1.22 \pm 0.20 \mathrm{~kg} ; 44.8 \pm 2 \mathrm{~cm} ; 4$ fish $)$ and female $(2.36 \pm 0.64 \mathrm{~kg} ; 55.1 \pm 2 \mathrm{~cm} ; 16$ fish) broodstock were maintained in the same tank. Both male and female broodstock were studied for their fads2 expression pattern in blood cells and liver. The tank was supplied with seawater $\left(37 \mathrm{~g} \mathrm{~L}^{-1}\right.$ salinity, $\left.17.0-20.0^{\circ} \mathrm{C}\right)$ at a daily water exchange rate of $600 \%$ and fish were maintained under natural photoperiod. All the broodstock were fed $1 \%$ body weight twice a day for one month with a diet containing low levels of fish meal (FM, 5\%) and fish oil (FO, 3\%) (Table 1). The experimental diet was produced by Biomar [48] and re-pelletized at the feed manufacturing facilities of GIA (ECOAQUA Institute, ULPGC, Las Palmas, Spain). The diet (Table 2) was formulated to contain high levels of vegetable oils and thus contained high levels of oleic acid (18:1n-9) $(32.3 \%$ of total fatty acids, TFA), LA (18:2n-6) (20.3\%TFA), and ALA (18:3n-3) (11.8 \%TFA) while containing low concentrations of EPA (2.5 \%TFA), DHA (1.7 \%TFA), and n-3 LC-PUFA (4.6\%TFA) in order to up-regulate the fatty acid desaturase 2 ( fads2) gene expression [48].

Table 1. Ingredients (\%) and proximate composition of the low fish meal and low fish oil diet fed to gilthead seabream broodstock.

\begin{tabular}{cc}
\hline Ingredients (\%) & Experimental Diet \\
\hline Fish meal (South American) & 5.00 \\
Blood meal (spray-dried) & 7.00 \\
Soya protein concentrate & 20.00 \\
Corn gluten meal & 22.00 \\
Wheat gluten & 5.50 \\
Rapeseed meal & 11.30 \\
Wheat & 6.89 \\
Fish oil (South American) & 3.00 \\
Linseed oil & 2.60 \\
Palm oil & 5.20 \\
Rapeseed oil & 5.20 \\
Supplemented ingredients ${ }^{2}$ & 5.49 \\
Vitamin and mineral premix ${ }^{2}$ & 0.75 \\
Antioxidant-Ethoxyquin & 0.05 \\
Yttrium oxide & 0.03 \\
\hline Proximate Composition & \\
\hline Crude protein (\% dry matter, DM) & 45.1 \\
Crude lipid (\% DM) & 21.7 \\
Ash (\% DM) & 5.4 \\
Moisture (\%) & 9.0 \\
\hline
\end{tabular}

\footnotetext{
${ }^{1}$ Supplemented ingredients contain-lysine, methionine, monocalcium phosphate, choline, inositol, phospholipids. ${ }^{2}$ Vitamin and mineral premix—vitamins (mg/kg): A 3.8, D 0.05, E 102.4, K3 9.8, B1 2.7, B2 8.3, B6 4.8, B12 0.25, B3 24.8, B5 17.2, folic acid 2.8, H 0.14, C 80; minerals (mg/kg): cobalt 0.94 , iodine 0.7 , selenium 0.2 , iron 32.6. manganese 12 , copper 3.2, zinc 67 ; other $(\mathrm{g} / \mathrm{kg})$ : taurine 2.45 , methionine 0.5 , histidine 1.36 , cholesterol 1.13 .
} 
Table 2. Fatty acid profiles of low fish meal and fish oil diet for gilthead seabream broodstock (\% total fatty acids).

\begin{tabular}{|c|c|}
\hline Fatty Acid (\%TFA) & Experimental Diet \\
\hline 14:0 & 6.6 \\
\hline $14: 1 n-5$ & 0.1 \\
\hline 15:0 & 0.1 \\
\hline 16:0 & 12.3 \\
\hline $16: 1 n-7$ & 2.1 \\
\hline $16: 1 n-5$ & 0.1 \\
\hline $16: 2 n-4$ & 0.2 \\
\hline 17:0 & 0.3 \\
\hline $16: 3 n-4$ & 0.1 \\
\hline $16: 4 n-3$ & 0.4 \\
\hline 18:0 & 3.2 \\
\hline $18: 1 n-9$ & 32.3 \\
\hline 18:1n-7 & 2.3 \\
\hline 18:2n-6 (LA) & 20.3 \\
\hline $18: 2 n-4$ & 0.1 \\
\hline $18: 3 n-6$ & 0.1 \\
\hline 18:3n-3 (ALA) & 11.8 \\
\hline $18: 4 n-3$ & 0.4 \\
\hline $20: 0$ & 0.4 \\
\hline $20: 1 n-9$ & 1.0 \\
\hline $20: 1 n-7$ & 0.1 \\
\hline $20: 2 n-6$ & 0.1 \\
\hline 20:4n-6 (ARA) & 0.2 \\
\hline $20: 4 n-3$ & 0.1 \\
\hline 20:5n-3 (EPA) & 2.5 \\
\hline 22:1n-11 & 0.1 \\
\hline $22: 1 n-9$ & 0.3 \\
\hline $22: 5 n-6$ & 0.1 \\
\hline 22:5n-3 (DPA) & 0.3 \\
\hline 22:6n-3 (DHA) & 1.7 \\
\hline Total saturates & 22.9 \\
\hline Total monoenes & 38.4 \\
\hline Total $n-3$ & 17.2 \\
\hline Total n-6 & 20.8 \\
\hline Total n-9 & 32.6 \\
\hline Total n-3 LC-PUFA & 4.6 \\
\hline
\end{tabular}

\subsection{Blood and Liver Sample Collection and Storage}

All broodfish $(\mathrm{n}=20)$ were fasted overnight and anesthetized with $10 \mathrm{ppm}$ clove oil (clove oil:methanol (50:50) in sea water) to collect peripheral blood and liver samples at the end of the feeding trial. After the feeding trial, blood samples were collected from the caudal vein of the GSB broodfish using sterile syringes and the whole blood samples were transferred to EDTA-coated tubes. Whole blood samples were centrifuged at $3000 \times g$ for $10 \mathrm{~min}$ held at $\left(4^{\circ} \mathrm{C}\right)$ to separate blood cells and plasma. The peripheral blood cell samples (PBCs) were stored at $-80^{\circ} \mathrm{C}$ until RNA extraction. Liver samples were collected from each fish and individually stored in a 1.5-mL Eppendorf tube containing RNA Later (Sigma-Aldrich, USA) and was snap frozen in liquid $\mathrm{N}_{2}$ immediately after sampling. The samples were then stored at $-80{ }^{\circ} \mathrm{C}$ until RNA extraction and analyses.

\subsection{Molecular Study—RNA Extraction and cDNA Synthesis}

Total RNA from PBCs (300-400 $\mu \mathrm{L}$ ) and liver samples $(60-70 \mathrm{mg})$ were extracted following the manufacturer's protocol using the RNeasy Mini Kit (Qiagen) and both blood cells and liver samples were completely homogenized with glass beads using the Tissue Lyzer-II (Qiagen, Hilden, Germany) 
with TRI Reagent (Sigma-Aldrich, San Luis, USA). Chloroform was added to the homogenized samples and centrifuged at $12,000 \times \mathrm{g}, 15 \mathrm{~min}, 4{ }^{\circ} \mathrm{C}$ for clear phase separation. The clear upper aqueous phase containing RNA was mixed with $75 \%$ ethanol and transferred into the RNeasy spin column, where total RNA bound to a membrane and RW1 $(700 \mu \mathrm{L})$ and RPE $(500 \mu \mathrm{L})$ buffers (Qiagen) were used to wash away contaminants. Total RNA from RNeasy spin column was eluted with $50 \mu \mathrm{L}$ of RNase-free water. The extracted total RNA quality and quantity were checked using a NanoDrop Spectrophotometer (Thermo Scientific, Wilmington, DE, USA). We used 100 ng RNA for the cDNA synthesis and it was carried out as following the standard protocol and cDNA synthesis was performed using the iScript cDNA Synthesis Kit (Bio-Rad) according to manufacturer's instructions in the iCycler thermal cycler (Bio-Rad, Hercules, CA, USA). The efficiency of $\Delta 6$ desaturase primer was tested with serial dilutions of a cDNA pool (1, 1:10, 1:100, 1:200 and 1:1000). Primers for GSB $\Delta 6$ desaturase were redesigned with reference to publications in NCBI (National Center for Biotechnology Information) as follows [30-33,43]:

Gene-fads2 ( $\Delta 6$ desaturase; GenBank: GQ162822.1)

Forward primer sequence $\left(5^{\prime} \rightarrow 3^{\prime}\right)$ GCAGAGCCACAGCAGCAGGGA

Reverse sequence $\left(3^{\prime} \rightarrow 5^{\prime}\right)$ CGGCCTGCGCCTGAGCAGTT

\subsection{Digital Droplet PCR (ddPCR) Analysis for Absolute Gene Expression}

Total RNA extraction from peripheral blood cells and liver were made using a similar protocol described above for the qPCR. Absolute gene expression of PBCs and liver fads2 analysis were performed using Digital Droplet PCR (ddPCR) (Bio-rad QX200, Hercules, CA, USA) systems, by using cDNA obtained as mentioned in Section 2.3. Sample preparation for ddPCR was carried out as per the manufacturer's protocol. The master mixes for fads 2 gene were prepared including $10 \mu \mathrm{L}$ EvaGreen super mix (Bio-rad, Hercules, CA, USA), $0.2 \mu \mathrm{L}$ F primer $(10 \mathrm{pmol} / \mu \mathrm{L}), 0.2 \mu \mathrm{L}$ R primer $(10 \mathrm{pmol} / \mu \mathrm{L})$, 7.6 $\mu \mathrm{L}$ MilQ water, and $2 \mu \mathrm{L}$ cDNA. Then, droplets were generated using droplet generator Bio-rad QX200 (Hercules, CA, USA) and the droplets were transferred to 96 well microplates for PCR in a thermal cycler (Bio-rad C1000 Touch, Hercules, CA, USA). After PCR amplifications, droplets were measured with a droplet reader (Bio-rad QX200, Hercules, CA, USA) to determine absolute gene expression of fads2 gene. The samples with less than 12,000 droplets were not used for the gene expression study. The fads 2 gene expression analysis was performed in two replicates for each sample and values were expressed as mRNA copies/ $\mu \mathrm{L}[31,33]$.

\subsection{Liver Fatty Acid Analysis}

Liver samples were collected from all the broodfish and stored at $-80^{\circ} \mathrm{C}$ for analysis of fatty acid composition. Crude lipid extraction was carried out with chloroform:methanol [49]. Hepatic fatty acids methyl esters (FAMES) from total lipids were prepared by transmethylation method with $1 \%$ sulfuric acid in methanol [50], purified on NH2 silica (Sep-pak; Waters), and separated and quantified in a gas chromatograph (GC14A; Shimadzu, Kyoto, Japan) equipped with a flame ionization detector and a Carbowax $20 \mathrm{M}(30 \mathrm{~m} \times 0.32 \mathrm{~mm} \times 0.27 \mathrm{~m})$ silica capillary column (length: $30 \mathrm{~m}$; internal diameter: $0.32 \mathrm{~mm}$; Supelco, Bellefonte, PA, USA) using helium as a carrier gas. Column initial temperature was set to $170{ }^{\circ} \mathrm{C}$ for $10 \mathrm{~min}$ and then it was raised to $220^{\circ} \mathrm{C}$ at $2.5^{\circ} \mathrm{C}$ per min and finally maintained at $215^{\circ} \mathrm{C}$ for a further $5 \mathrm{~min}$. FAMES were identified by comparison with previously characterized standards [51]. Specific unclear peaks were identified by GLC-MS (TRACE ${ }^{\mathrm{TM}}$ GC Ultra and PolarisQ mass spectrometer; Thermo Fisher Scientific, Spain).

\subsection{Ethical Statement}

The fish broodstock study was conducted as per guidelines of the European Union Directive (2010/63/EU) on the protection of animals for scientific purposes. The study was conducted at Aquaculture Research Group (GIA), ECOAQUA, University of Las Palmas de Gran Canaria (ULPGC), 
Canary Islands, Spain as per the ethical committee norms. All these samplings and studies were approved by the Bioethical Committee of the ULPGC vide REF: 007/2012 CEBA ULPGC.

\subsection{Statistical Analysis}

All results were reported as mean \pm standard deviation. All data was checked for normality (Kolmogorov-Smirnoff) and homogeneity (Levene's tests) and if no normality was observed, an arcsine transformation was performed to attain normality. All of the percentage data were arcsine-transformed before performing statistical analysis. The regression and Pearson's correlation analysis were performed for studying the relationship between fads 2 expression in PBCs and liver and between sex and broodstock body weight. The independent sample student's $t$-test was performed to compare male $(n=4)$ and female $(n=16)$ broodstock for body weight, hepatosomatic index (HSI \%), gonadosomatic index (GSI \%), PBCs, liver fads2 expression, and hepatic fatty acid composition. Pearson's correlation coefficient was calculated for liver fads 2 expression on hepatic fatty acid of either male or female broodstock. All data was analyzed using the program IBM SPSS version 20 for Windows (IBM SPSS Inc, Armonk, NY, USA).

\section{Results}

\subsection{Biometric and fads2 Expression Values for Males and Females}

The GSB male and female broodstock size, HSI \%, GSI \%, and fads2 expression in PCBs and liver are presented in Table 3. As expected, mean body length and weight were significantly higher for females than for males (Table 3$)$. The mean HSI values for males $(1.26 \pm 0.17)$ was $18 \%$ higher $(p=0.04)$ than for females $(1.08 \pm 0.13)$ (Table 3$)$, whereas GSI \% values for females $(1.47 \pm 0.36)$ were about 2.5 times higher $(p<0.001)$ than for males $(0.65 \pm 0.16)$ (Table 3$)$. HSI values for each individual fish ranged between $1.06-1.48$ and $0.83-1.48 \%$ for male and female broodstock, respectively (Figure 2), whereas those for GSI ranged from $0.47-0.80$ and from $1.01-2.37 \%$ for male and female broodstock, respectively (Figure 2).

Table 3. Gilthead seabream male and female broodstock body length $(\mathrm{cm})$, weight $(\mathrm{kg}), \mathrm{HSI} \%$, GSI \%, and PBCs and liver fads2 expression (mRNA copies/ $\mu \mathrm{L}$ ) after feeding the low fish meal and fish oil diet for one month. Superscript "a" or " $b$ " indicates significantly higher or lower mean value, respectively.

\begin{tabular}{cccc}
\hline Broodstock & Males $(\mathbf{n}=4)$ & Female $(\mathbf{n}=16)$ & $t$-Test $(\boldsymbol{p}$-Value $)$ \\
\hline Body length $(\mathrm{cm})$ & $47 \pm 3^{\mathrm{b}}$ & $56 \pm 4^{\mathrm{a}}$ & $<0.001$ \\
Body weight $(\mathrm{kg})$ & $1.27 \pm 0.19^{\mathrm{b}}$ & $2.40 \pm 0.63^{\mathrm{a}}$ & 0.003 \\
HSI $(\%)$ & $1.26 \pm 0.17^{\mathrm{a}}$ & $1.08 \pm 0.13^{\mathrm{b}}$ & 0.04 \\
GSI $(\%)$ & $0.65 \pm 0.16^{\mathrm{b}}$ & $1.47 \pm 0.36^{\mathrm{a}}$ & $<0.001$ \\
PBCs fads2 (mRNA copies $/ \mu \mathrm{L})$ & $1.68 \pm 0.55$ & $2.00 \pm 0.93$ & 0.52 \\
Liver fads2 (mRNA copies $/ \mu \mathrm{L})$ & $2.60 \pm 0.84$ & $3.24 \pm 1.49$ & 0.43 \\
\hline
\end{tabular}

Different superscripts in each row indicate significant differences among male or female broodfish $(p<0.05$, Independent Sample student's $t$-test). HSI (\%) (hepatosomatic index $)=($ Liver weight, $g /$ weight of fish, g) $\times 100$; GSI $(\%)($ gonadosomatic index $)=($ Gonad weight, $\mathrm{g} /$ weight of fish, $\mathrm{g}) \times 100$.

The mean PBC fads2 expression of male and females were $1.68 \pm 0.55$ and $2.00 \pm 0.93$ copies $/ \mu \mathrm{L}$, respectively and liver fads 2 expression was $2.60 \pm 0.84$ and $3.24 \pm 1.49$ copies $/ \mu \mathrm{L}$ for male and female broodstock, respectively (Table 3 ). There was a very high coefficient of variation in the fads 2 expression levels in both males (32\%) and females (46\%). The Student $t$-test showed that the fads 2 expression in PBCs or liver was not significantly $(p>0.05)$ different between males and females, although fads2 values in PBCs and liver were 20 and 25\% higher in females than in males (Table 3). No significant correlation was found between body weight and HSI (\%) or between body weight and GSI (\%) of either male or female broodstock (Table 4). 


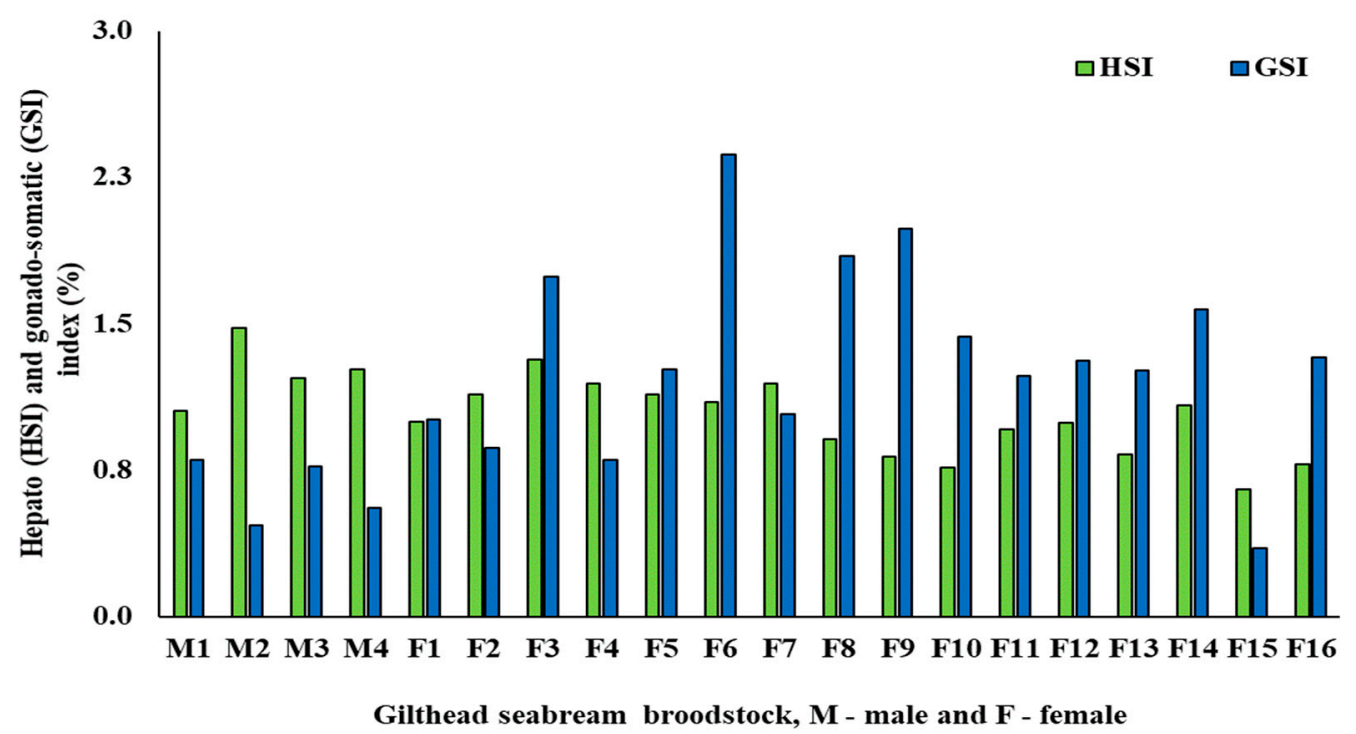

Figure 2. HSI (hepatosomatic index) or GSI (gonadosomatic index) (\%) of gilthead seabream male $(\mathrm{n}=4)$ or female $(\mathrm{n}=16)$ broodstock (M1 to M4-Male; F1 to F16-Female).

Table 4. Pearson's correlation of body weight (kg) and HSI or GSI (\%) of male and female gilthead seabream broodstock.

\begin{tabular}{ccccc}
\hline \multirow{2}{*}{ Broodstock } & \multicolumn{2}{c}{ Male Broodstock } & \multicolumn{2}{c}{ Female Broodstock } \\
\cline { 2 - 5 } & HSI (\%) & GSI (\%) & HSI (\%) & GSI (\%) \\
\hline Body weight $(\mathrm{kg})$ & $-0.35(0.65)$ & $0.14(0.86)$ & $0.14(0.61)$ & $0.25(0.36)$ \\
\hline
\end{tabular}

\subsection{Comparison of fads2 Expression in PBC or in Liver and Broodstock Body Weight}

Expression of fads2 in PBCs was not correlated to body weight in males $(\mathrm{r}=-0.56 ; p=0.45)$, females $(\mathrm{r}=0.15 ; p=0.58)$ nor both sexes $(\mathrm{r}=0.19 ; p=0.42)$ broodstock (Table 5). In males, we found a significant negative correction $(r=-0.96 ; p=0.04)$ between liver fads 2 expression and body weight, whereas in females liver fads2 expression did not show any correlation $(\mathrm{r}=0.13 ; p=0.64)$ to body weight (Table 5). Moreover, we could not find any correlation between broodfish body weight and liver fads2 expression $(\mathrm{r}=0.19 ; p=0.43)$ in either sex. Moreover, neither fads2 expression in PBCs nor in liver showed a significant regression with body weight for males, females or both sexes $(p>0.05$; data not showed).

Table 5. Pearson's correlation coefficient (PC) of body weight $(\mathrm{kg})$ and PBCs or liver fads2 expression (mRNA copies $/ \mu \mathrm{L}$ ) of male, female, and both male and female gilthead seabream broodstock.

\begin{tabular}{ccccccc}
\hline \multirow{2}{*}{ Broodstock } & \multicolumn{2}{c}{ Male Broodstock } & \multicolumn{2}{c}{ Female Broodstock } & \multicolumn{2}{c}{ Male and Female Broodstock } \\
\cline { 2 - 7 } & PBCs fads2 & Liver fads2 & PBCs fads2 & Liver fads2 & PBCs fads2 & Liver fads2 \\
\hline Body weight $(\mathrm{kg})$ & $-0.56(0.45)$ & $-0.96(0.04)$ & $0.15(0.58)$ & $0.13(0.64)$ & $0.19(0.42)$ & $0.19(0.43)$ \\
\hline
\end{tabular}

\subsection{Relationship between fads2 Expression in PBCs and in Liver of Male and Female Broodstock}

Individual data on fads2 expression in PBCs and liver of male and female broodstock are presented in Figure 3. The fads2 expression values in PBCs and liver of male broodstock did not significantly $(p=0.114)$ differ (Table 6$)$ and Pearson's correlation analysis showed a positive $(\mathrm{r}=0.76)$, but not significant $(p=0.24)$, correlation between both parameters (Table 7). On the contrary, fads 2 expression was significantly lower in PBCs compared to the liver for females $(p=0.008)$ and both sexes $(p=0.003)$ (Table 6). Additionally, female broodstock exhibited a highly positive $(\mathrm{r}=0.90)$ and very significant $(p<0.001)$ correlation in the fads 2 expression between PBCs and liver. The same trend was observed for 
PBCs and liver fads2 gene expression of pooled results for both male and female broodstock $(\mathrm{r}=0.89$; $p<0.001$ ) (Table 7). The regression relationship analysis results for males and females showed that data for females $\left(R^{2}=0.88 ; p<0.001\right)$ and for both sexes combined $\left(R^{2}=0.85 ; p<0.001\right)$ exhibited a significantly higher level of regression between PBCs and liver fads 2 expression than in male broodstock $\left(\mathrm{R}^{2}=0.51 ; p=0.29\right)$ (Figure 4).

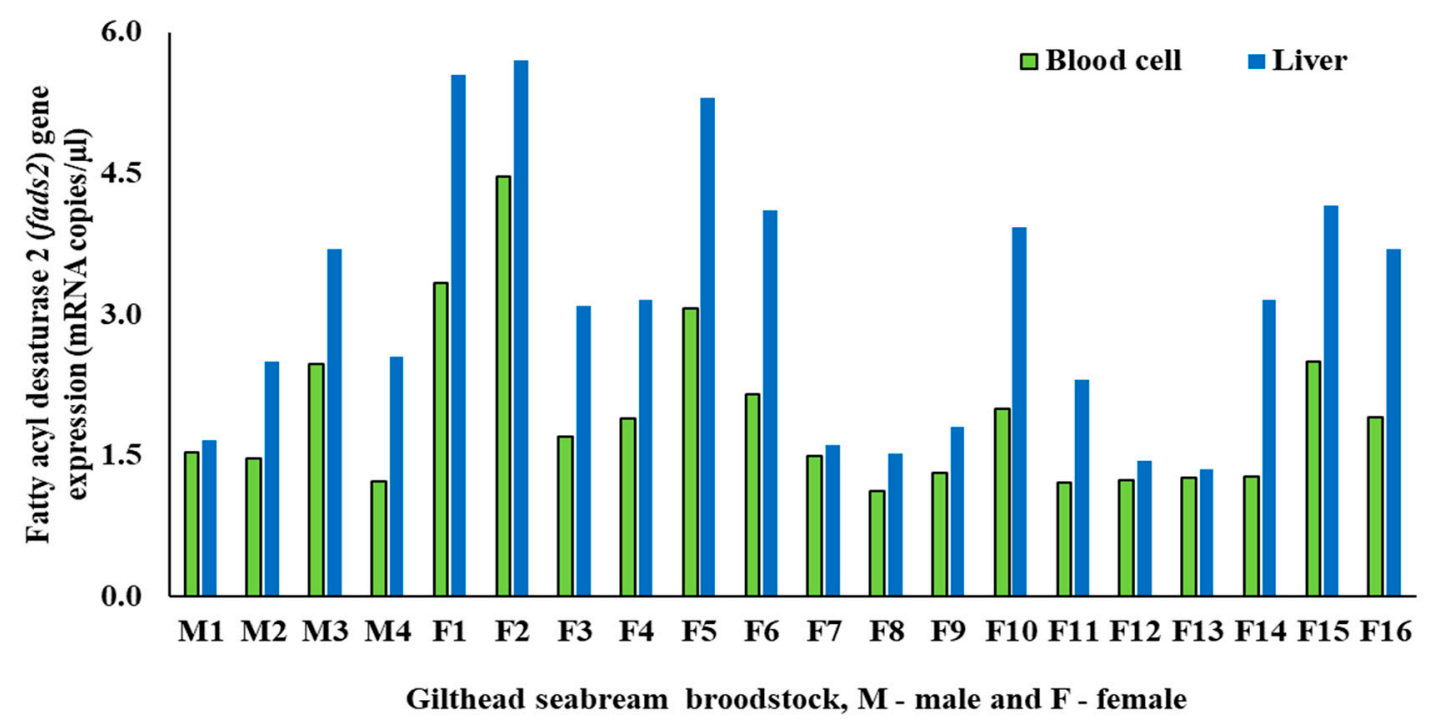

Figure 3. Fatty acyl desaturase 2 (fads2) mRNA expression (copies/ $\mu \mathrm{l}$ ) in PBCs or liver of gilthead seabream male $(n=4)$ and female $(n=16)$ broodstock (M1 to M4-male; F1 to F16-female).

Table 6. Independent sample student's $t$-test of PBCs and liver fads2 expression (mRNA copies $/ \mu \mathrm{L}$ ) in male, female, and both male and female gilthead seabream broodstock.

\begin{tabular}{cccc}
\hline Broodstock & PBCs fads 2 & Liver fads 2 & $t$-Test $(p$-Value) \\
\hline Male & $1.68 \pm 0.55$ & $2.60 \pm 0.84$ & 0.114 \\
Female & $2.00 \pm 0.93^{\mathrm{b}}$ & $3.24 \pm 1.49^{\mathrm{a}}$ & 0.008 \\
Male and female & $1.93 \pm 0.87^{\mathrm{b}}$ & $3.11 \pm 1.39^{\mathrm{a}}$ & 0.003 \\
\hline
\end{tabular}

Different superscripts in each row indicate significant differences $(p<0.05$, Independent sample student's $t$-test).

Table 7. Pearson's correlation coefficient (PC) of PBCs and liver fads2 expression (mRNA copies/ $\mu \mathrm{L}$ ) in male, female, and both male and female gilthead seabream broodstock.

\begin{tabular}{cccc}
\hline & Male Broodstock & Female Broodstock & Male and Female Broodstock \\
\hline & & Liver fads2 \\
\hline PBCs fads2 & $0.76(0.24)$ & $0.90(<0.001)$ & $0.89(<0.001)$ \\
\hline
\end{tabular}

\subsection{Fatty Acid Composition of the Liver}

Liver fatty acid profiles were very similar between males and females (Table 8). Thus, mean content in each fatty acid was not significantly different between males and females, except for 16:4n-3 fatty acid, which was $47 \%$ higher $(p=0.01)$ in males (Table 8$)$. Consequently, the sum of fatty acids belonging to saturated, monounsaturated, $n-9, n-6$, or $n-3$ families were not significantly different between males and females $(p>0.05)$ (Table 8). Similarly, there were no significant differences in the ratios among main essential fatty acids $(p>0.05)$ observed (Table 8$)$. Fatty acid profiles of individual broodfish markedly differed among individuals, including fatty acids of interest in the bioconversion pathway (Supplementary Table S1). For instance, EPA levels in males ranged between 1.5 to $4.5 \%$ and in females between 1.5 to $5.0 \%$, whereas DHA levels were higher than those of EPA with individual values ranging between 5.2 to $13.7 \%$ in males and between 6.0 to $14.4 \%$ in females (Supplementary 
Table S1). Among the males, the one with the highest liver fads2 expression (M3) and the lowest weight showed the highest hepatic ARA, DHA, total n-3 LC-PUFA, or EPA+DHA contents (Supplementary Table S1). However, among the females, the one with the highest fads2 expression (F2) did not show the highest levels of these fatty acids (Supplementary Table S1).
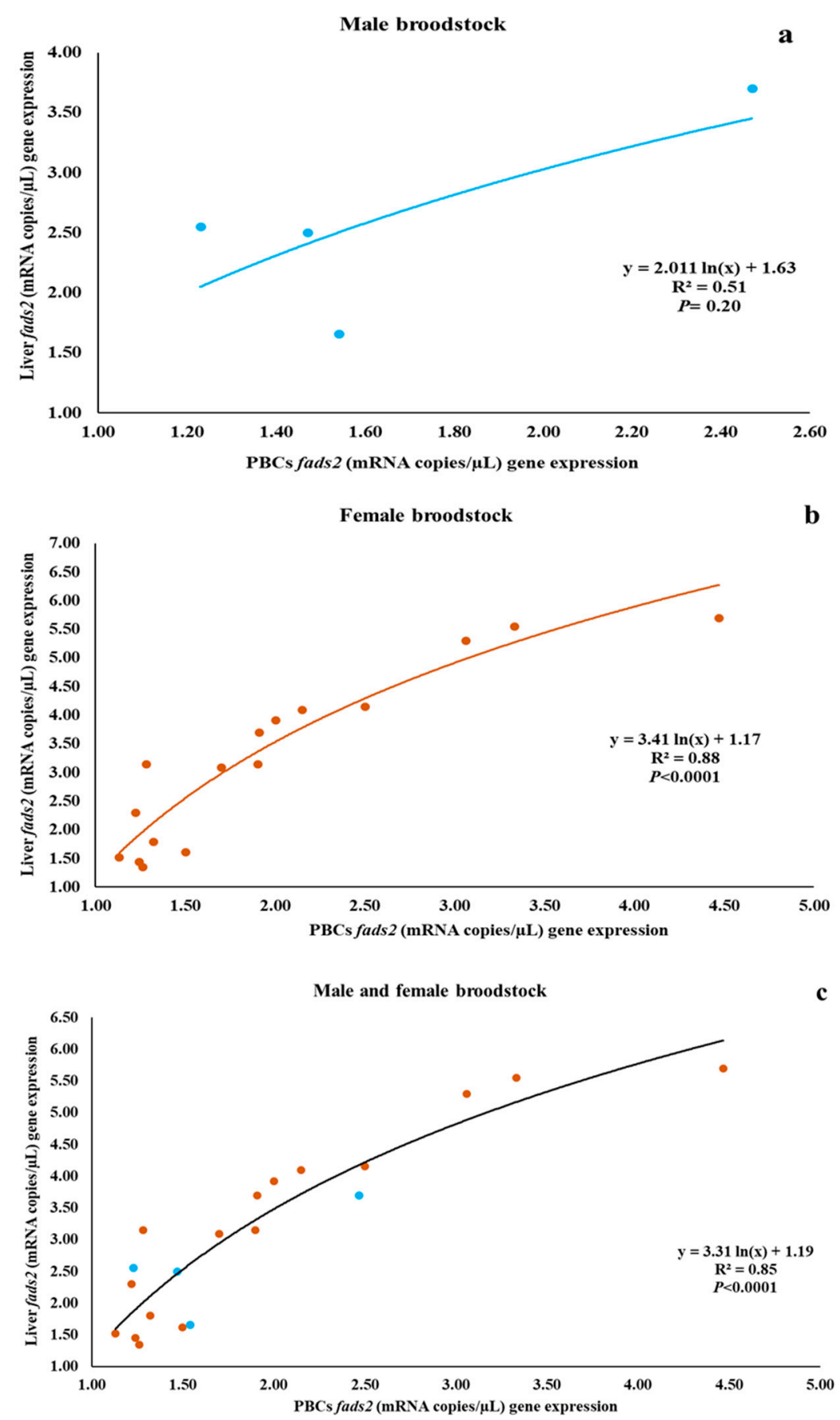

Figure 4. The regression relationship between PBCs and liver fads2 mRNA expression (copies/ $\mu \mathrm{L}$ ) in gilthead seabream male $(n=4)(a)$, female $(n=16)(b)$, or both $(n=20)(c)$ broodstock. 
Table 8. Mean hepatic fatty acid composition (\% total fatty acids) of male or female gilthead seabream broodstock after feeding the low fish meal and fish oil diet for one month.

\begin{tabular}{|c|c|c|c|c|c|}
\hline \multirow{2}{*}{ Fatty Acid (\%TFA) } & \multicolumn{2}{|c|}{ Male } & \multicolumn{2}{|c|}{ Female } & \multirow{2}{*}{$t$-Test ( $p$-Value) } \\
\hline & Mean & SD & Mean & SD & \\
\hline 14:0 & 1.42 & 0.57 & 1.30 & 0.38 & 0.59 \\
\hline $14: 1 n-5$ & 0.04 & 0.02 & 0.03 & 0.01 & 0.33 \\
\hline $14: 1 n-7$ & 0.02 & 0.01 & 0.03 & 0.01 & 0.70 \\
\hline 15:0 & 0.17 & 0.03 & 0.14 & 0.04 & 0.19 \\
\hline $15: 1 n-5$ & 0.02 & 0.01 & 0.02 & 0.01 & 0.82 \\
\hline 16:0 & 11.56 & 0.29 & 11.41 & 1.42 & 0.72 \\
\hline $16: 1 n-7$ & 2.48 & 1.12 & 2.18 & 0.46 & 0.64 \\
\hline $16: 1 n-5$ & 0.06 & 0.02 & 0.05 & 0.01 & 0.43 \\
\hline $16: 2 n-4$ & 0.14 & 0.11 & 0.10 & 0.04 & 0.48 \\
\hline 17:0 & 0.14 & 0.08 & 0.11 & 0.04 & 0.35 \\
\hline $16: 3 n-4$ & 0.16 & 0.03 & 0.14 & 0.02 & 0.30 \\
\hline $16: 3 n-3$ & 0.06 & 0.02 & 0.05 & 0.01 & 0.40 \\
\hline $16: 3 n-1$ & 0.04 & 0.04 & 0.03 & 0.01 & 0.76 \\
\hline $16: 4 n-3$ & $0.17^{\mathrm{a}}$ & 0.06 & $0.09^{b}$ & 0.04 & 0.01 \\
\hline $18: 1 n-9$ & 3.86 & 0.95 & 3.80 & 0.45 & 0.66 \\
\hline $18: 1 n-7$ & 28.81 & 3.98 & 29.80 & 1.61 & 0.67 \\
\hline $18.1 n-5$ & 2.69 & 0.35 & 2.61 & 0.15 & 0.76 \\
\hline $18: 2 n-9$ & 0.11 & 0.03 & 0.10 & 0.03 & 0.30 \\
\hline $18: 2 n-6$ (LA) & 0.09 & 0.05 & 0.11 & 0.04 & 0.71 \\
\hline $18: 2 n-4$ & 14.51 & 2.52 & 14.86 & 1.41 & 0.77 \\
\hline $18: 3 n-6$ & 0.09 & 0.04 & 0.09 & 0.02 & 0.61 \\
\hline $18: 3 n-4$ & 0.24 & 0.07 & 0.25 & 0.06 & 0.56 \\
\hline 18:3n-3 (ALA) & 0.13 & 0.03 & 0.12 & 0.03 & 0.43 \\
\hline $18.3 n-1$ & 9.01 & 3.24 & 9.92 & 1.68 & 0.45 \\
\hline $18: 4 n-3$ & 0.01 & 0.01 & 0.00 & 0.01 & 0.72 \\
\hline $18: 4 n-1$ & 0.55 & 0.29 & 0.49 & 0.13 & 0.82 \\
\hline 20:0 & 0.09 & 0.04 & 0.08 & 0.03 & 0.45 \\
\hline $20: 1 n-9$ & 0.29 & 0.02 & 0.26 & 0.06 & 0.71 \\
\hline $20: 1 n-7$ & 0.36 & 0.18 & 0.33 & 0.11 & 0.66 \\
\hline $20.1 n-5$ & 2.34 & 0.72 & 2.22 & 0.42 & 0.86 \\
\hline $20: 2 n-9$ & 0.15 & 0.05 & 0.15 & 0.06 & 0.24 \\
\hline $20: 2 n-6$ & 0.18 & 0.05 & 0.23 & 0.08 & 0.34 \\
\hline $20: 3 n-9$ & 0.86 & 0.18 & 0.94 & 0.15 & 0.88 \\
\hline $20: 3 n-6$ & 0.03 & 0.01 & 0.03 & 0.01 & 0.60 \\
\hline $20: 4 n-6$ (ARA) & 0.26 & 0.16 & 0.29 & 0.10 & 0.74 \\
\hline $20: 3 n-3$ & 0.77 & 0.64 & 0.66 & 0.18 & 0.17 \\
\hline $20: 4 n-3$ & 0.78 & 0.28 & 0.95 & 0.19 & 0.76 \\
\hline 20:5n-3 (EPA) & 0.66 & 0.17 & 0.68 & 0.13 & 0.75 \\
\hline $22: 1 n-11$ & 2.80 & 1.26 & 2.61 & 1.00 & 0.50 \\
\hline $22: 1 n-9$ & 1.48 & 0.92 & 1.22 & 0.62 & 0.97 \\
\hline $22: 4 n-6$ & 0.65 & 0.18 & 0.65 & 0.18 & 0.35 \\
\hline $22: 5 n-6$ & 0.23 & 0.13 & 0.18 & 0.06 & 0.56 \\
\hline 22:5n-3 (DPA) & 0.19 & 0.08 & 0.18 & 0.05 & 0.66 \\
\hline $22: 6 n-3$ (DHA) & 2.04 & 0.78 & 1.88 & 0.57 & 0.61 \\
\hline Total Saturates & 9.32 & 3.73 & 8.57 & 2.30 & 0.66 \\
\hline Total Monoenes & 17.43 & 0.73 & 17.02 & 1.77 & 0.90 \\
\hline Total n-3 & 39.20 & 5.71 & 39.40 & 1.90 & 0.94 \\
\hline Total n-6 & 25.37 & 3.44 & 25.24 & 2.76 & 0.86 \\
\hline Total n-9 & 17.05 & 3.08 & 17.36 & 1.39 & 0.64 \\
\hline Total n-3 LC-PUFA & 30.11 & 4.01 & 31.15 & 1.38 & 0.69 \\
\hline $\mathrm{EPA}+\mathrm{DHA}$ & 15.59 & 5.04 & 14.69 & 3.68 & 0.62 \\
\hline ARA/EPA & 12.12 & 4.44 & 11.18 & 3.11 & 0.82 \\
\hline EPA/ARA & 0.31 & 0.27 & 0.28 & 0.12 & 0.64 \\
\hline
\end{tabular}


Table 8. Cont.

\begin{tabular}{cccccc}
\hline \multirow{2}{*}{ Fatty Acid (\%TFA) } & \multicolumn{2}{c}{ Male } & \multicolumn{2}{c}{ Female } & \multirow{2}{*}{$\boldsymbol{t}$-Test $(\boldsymbol{p}$-Value) } \\
\cline { 2 - 5 } & Mean & SD & Mean & SD & \\
\hline DHA/ARA & 5.01 & 3.05 & 4.19 & 1.69 & 0.66 \\
DHA/EPA & 14.72 & 5.44 & 13.36 & 2.97 & 0.83 \\
DHA/DPA & 3.57 & 1.48 & 3.46 & 0.80 & 0.88 \\
n-3/n-6 & 4.82 & 2.20 & 4.64 & 0.84 & 0.74 \\
n-6/n-3 & 1.52 & 0.32 & 1.47 & 0.26 & 0.78 \\
18:2n-9/18:1n-9 & 0.68 & 0.13 & 0.70 & 0.10 & 0.79 \\
18:3n-6/18:2n-6 & 0.66 & 0.54 & 0.75 & 0.34 & 0.86 \\
20:3n-6/20:2n-6 & 0.02 & 0.01 & 0.02 & 0.01 & 0.71 \\
18:4n-3/18:3n3 & 0.29 & 0.12 & 0.31 & 0.09 & 0.52 \\
20:4n-3/20:3n-3 & 0.08 & 0.06 & 0.05 & 0.03 & 0.48 \\
\hline
\end{tabular}

Different superscripts in each row indicate significant differences among male or female broodfish hepatic fatty acid composition $(p<0.05$, Independent sample student's $t$-test).

To determine the relationship between liver fads2 expression and hepatic fatty acid composition, a Pearson's correlation analysis was conducted (Table 9). In male broodstock, liver fads2 expression was highly $(p<0.05)$ correlated to 20:3n-6/20:2n-6 ( $\mathrm{r}=0.98)$, a fads2 product/precursor ratio, and slightly $(p<0.1)$ correlated to 20:3n-9 $(r=0.94), 20: 3 n-6(r=0.91), 22: 4 n-6(r=0.91), 22: 5 n-6(r=0.93)$, and 22:6n-3 $(\mathrm{r}=0.92)$, all of them direct or indirect products from Fads2 activity. In females, none of the hepatic FAs showed significant $(p>0.05)$ correlations with liver fads2 expression.

Table 9. Pearson's correlation of liver fads2 expression (mRNA copies/ $\mu \mathrm{L}$ ) and hepatic fatty acid (\%TFA) composition of male and female gilthead seabream broodstock.

\begin{tabular}{|c|c|c|c|c|}
\hline \multirow{2}{*}{ Fatty Acids (\%TFA) } & \multicolumn{2}{|c|}{ Male Broodstock } & \multicolumn{2}{|c|}{ Female Broodstock } \\
\hline & Pearson's Correlation & $p$-Value & Pearson' Correlation & $p$-Value \\
\hline 14:0 & -0.57 & 0.43 & -0.07 & 0.79 \\
\hline $14: 1 n-5$ & -0.58 & 0.42 & -0.22 & 0.42 \\
\hline $14: 1 n-7$ & -0.89 & 0.11 & -0.12 & 0.66 \\
\hline 15:0 & -0.57 & 0.43 & -0.20 & 0.45 \\
\hline $15: 1 n-5$ & -0.43 & 0.57 & -0.33 & 0.21 \\
\hline 16:0 & 0.95 & 0.04 & 0.25 & 0.35 \\
\hline $16: 1 n-7$ & -0.40 & 0.60 & -0.13 & 0.62 \\
\hline $16: 1 n-5$ & -0.11 & 0.89 & -0.04 & 0.88 \\
\hline $16: 2 n-4$ & -0.37 & 0.63 & -0.17 & 0.52 \\
\hline 17:0 & -0.15 & 0.85 & -0.31 & 0.24 \\
\hline $16: 3 n-4$ & -0.70 & 0.30 & 0.04 & 0.87 \\
\hline $16: 3 n-3$ & -0.11 & 0.89 & -0.33 & 0.22 \\
\hline $16: 3 n-1$ & 0.85 & 0.15 & -0.48 & 0.06 \\
\hline $16: 4 n-3$ & 0.32 & 0.68 & -0.19 & 0.48 \\
\hline 18:0 & 0.83 & 0.17 & 0.45 & 0.08 \\
\hline $18: 1 n-9$ & -0.75 & 0.25 & 0.28 & 0.29 \\
\hline $18: 1 n-7$ & -0.42 & 0.58 & 0.03 & 0.90 \\
\hline $18.1 n-5$ & -0.10 & 0.90 & -0.19 & 0.48 \\
\hline $18: 2 n-9$ & 0.86 & 0.14 & 0.05 & 0.85 \\
\hline $18: 2 n-6$ (LA) & -0.10 & 0.90 & 0.11 & 0.69 \\
\hline $18: 2 n-4$ & -0.11 & 0.89 & -0.39 & 0.14 \\
\hline $18: 3 n-6$ & 0.93 & 0.07 & -0.04 & 0.89 \\
\hline $18: 3 n-4$ & -0.11 & 0.89 & -0.14 & 0.61 \\
\hline 18:3n-3 (ALA) & -0.37 & 0.63 & 0.10 & 0.72 \\
\hline $18.3 n-1$ & -0.11 & 0.89 & 0.20 & 0.46 \\
\hline $18: 4 n-3$ & -0.16 & 0.84 & -0.22 & 0.41 \\
\hline $18: 4 n-1$ & -0.39 & 0.61 & -0.34 & 0.20 \\
\hline
\end{tabular}


Table 9. Cont.

\begin{tabular}{|c|c|c|c|c|}
\hline \multirow{2}{*}{ Fatty Acids (\%TFA) } & \multicolumn{2}{|c|}{ Male Broodstock } & \multicolumn{2}{|c|}{ Female Broodstock } \\
\hline & Pearson's Correlation & $p$-Value & Pearson' Correlation & $p$-Value \\
\hline 20:0 & 0.14 & 0.86 & -0.35 & 0.18 \\
\hline $20: 1 n-9$ & -0.40 & 0.60 & -0.24 & 0.38 \\
\hline $20: 1 n-7$ & -0.44 & 0.56 & -0.29 & 0.29 \\
\hline $20.1 n-5$ & -0.27 & 0.73 & -0.17 & 0.52 \\
\hline $20: 2 n-9$ & 0.86 & 0.14 & 0.28 & 0.29 \\
\hline $20: 2 n-6$ & 0.49 & 0.51 & 0.19 & 0.49 \\
\hline $20: 3 n-9$ & 0.94 & 0.07 & -0.14 & 0.60 \\
\hline $20: 3 n-6$ & 0.91 & 0.09 & 0.23 & 0.40 \\
\hline $20: 4 n-6$ (ARA) & 0.89 & 0.11 & -0.03 & 0.91 \\
\hline $20: 3 n-3$ & 0.31 & 0.69 & 0.30 & 0.26 \\
\hline $20: 4 n-3$ & 0.62 & 0.38 & -0.03 & 0.92 \\
\hline $20: 5 n-3$ (EPA) & 0.20 & 0.80 & -0.29 & 0.27 \\
\hline 22:1n-11 & -0.25 & 0.75 & -0.29 & 0.27 \\
\hline $22: 1 n-9$ & -0.33 & 0.67 & -0.12 & 0.65 \\
\hline $22: 4 n-6$ & 0.91 & 0.09 & -0.06 & 0.83 \\
\hline $22: 5 n-6$ & 0.93 & 0.07 & -0.11 & 0.69 \\
\hline $22: 5 n-3$ (DPA) & 0.12 & 0.88 & -0.21 & 0.45 \\
\hline $22: 6 n-3$ (DHA) & 0.92 & 0.08 & -0.21 & 0.44 \\
\hline Total Saturates & 0.97 & 0.03 & 0.28 & 0.30 \\
\hline Total Monoenes & -0.76 & 0.24 & 0.01 & 0.96 \\
\hline Total n-3 & 0.80 & 0.20 & -0.26 & 0.34 \\
\hline Total n-6 & 0.26 & 0.74 & 0.14 & 0.62 \\
\hline Total n-9 & -0.76 & 0.25 & 0.31 & 0.24 \\
\hline Total n-3 LC-PUFA & 0.79 & 0.21 & -0.23 & 0.40 \\
\hline $\mathrm{EPA}+\mathrm{DHA}$ & 0.83 & 0.17 & -0.25 & 0.36 \\
\hline ARA/EPA & 0.72 & 0.28 & 0.14 & 0.61 \\
\hline EPA/ARA & -0.40 & 0.60 & -0.25 & 0.35 \\
\hline DHA/ARA & -0.45 & 0.55 & -0.21 & 0.44 \\
\hline DHA/EPA & 0.69 & 0.31 & 0.20 & 0.46 \\
\hline DHA/DPA & 0.81 & 0.19 & -0.02 & 0.94 \\
\hline n-3/n-6 & 0.24 & 0.76 & -0.27 & 0.31 \\
\hline n-6/n-3 & -0.38 & 0.62 & 0.21 & 0.43 \\
\hline $18: 2 n-9 / 18: 1 n-9$ & 0.87 & 0.13 & -0.04 & 0.90 \\
\hline $20: 2 n-9 / 20: 1 n-9$ & 0.89 & 0.11 & 0.30 & 0.27 \\
\hline $18: 3 n-6 / 18: 2 n-6$ & 0.75 & 0.25 & -0.32 & 0.23 \\
\hline $20: 3 n-6 / 20: 2 n-6$ & 0.98 & 0.02 & 0.15 & 0.58 \\
\hline $18: 4 n-3 / 18: 3 n 3$ & -0.04 & 0.96 & -0.15 & 0.58 \\
\hline $20: 4 n-3 / 20: 3 n-3$ & 0.05 & 0.95 & -0.26 & 0.32 \\
\hline
\end{tabular}

\section{Discussion}

Fads2 is a rate-limiting enzyme involved in the first step of LC-PUFA biosynthesis in all vertebrates. In many marine fish, including gilthead seabream (GSB), its activity is low and the expression of the gene responsible for its production (fads2) is very low [1,17,30,31]. Fads2 has dual $\Delta 6$ or $\Delta 8$ activities in many marine fish including GSB [19,32]. An increase in fads2 expression may result in higher $\Delta 6$ Fads production, yielding a higher production of essential fatty acids in fish [31,32]. The implication of the fads 2 gene expression pattern in male and female animals has been studied to elucidate its importance on reproductive performance in higher vertebrates $[45-47,52,53]$ and in fish $[31,33]$. However, there are no previous studies determining the potential relationship between male and female body weight and fads2 expression in different tissues. As expected from a protandric hermaphrodite species, females showed a significantly higher body weight than males. However, there were no significant relationships between fads2 expression in PCBs and the body weight of males, females, or both sexes in broodstock observed. These results are in accordance with our previous 
studies, in which no correlations were found between either parameters [31]. Moreover, there was no significant correlation of body weight with fads2 expression in the liver of females nor in both sexes in broodstock noticed. However, the highest liver fads2 expression found in male broodstock with the lowest body weight (M3), which could be related to individual differences in the genome or epigenome, in agreement with our studies [31,33]. These results indicated that there is no relationship between broodstock body weight and the relative expression of fads 2 in PBCs or liver.

Our previous studies on reproductive performance of GSB have found that, during the spawning season, female broodstock shows higher fads2 expression in PBC compared to male broodstock [31]. Moreover, in GSB females, there is a significant positive correlation between the plasma 17 $\beta$-estradiol levels and the fads 2 expression in PBC in accordance with studies reported in mammals [45,54-56]. In agreement with the present study, fads2 expression in PBCs and in liver were respectively 20 and $25 \%$ higher in females than in males, but were not significantly different. This lack of significance could be due to the fact that the present study was conducted prior to the spawning season, when female gametogenesis was being initiated and GSI still remained low, but was significantly higher than that of males. Therefore, $17 \beta$-estradiol levels, directly related to the fads 2 expression in PBC, could be expected to still be relatively low. Indeed, fatty acid profiles of liver in females showed $7-28 \%$ higher Fads2-derived fatty acid products from n-9 and n-6 series than in male livers. However, n-3 fads2-derived fatty acids tend to be higher in males. These differences among fatty acid families showed that the fatty acid profile of a tissue is not only related to the desaturation activity. For instance, during exogenous vitellogenesis in female liver, there is an increased synthesis of lipoproteins, particularly phosvitin and lipovitelin rich in n-3 LC-PUFA, which transports lipids to the developing oocyte [57]. In agreement with the present study, the GSI was significantly $(p<0.001)$ higher in females than in males, whereas the HSI was $18 \%$ lower $(p=0.04)$ than in males, suggesting the mobilization of nutrients from liver to gonads. These results agree with the higher GSI observed in female in comparison to males [58-60]. In addition, increased fads 2 expression in male liver led to increased contents of 20:3n-6/20:2n-6, a fads2 product/precursor ratio, and a slight increase of 20:3n-9, 20:3n-6, 22:4n-6, 22:5n-6, and 22:6n-3, suggesting an increase in lipogenesis pathways. These results agree well with the increased expression of fatty acid synthase genes ( $f a s$ ) found in the liver of seabream with increased fads2 expression [61]. Higher fads2 expression in GSB females in comparison to males would be justified by their high EFA requirements during vitellogenesis $[30,62]$ to supply vital nutrients to the gamete and embryo [30,63-66]. Besides, LC-PUFA, including ARA and EPA, are required as precursors for the production of prostaglandins [67] that regulate steroidogenesis, which in turn induce vitellogenin synthesis in liver [68-70]. Therefore, the high variability in liver fatty acid profiles of individual brood fish could reflect the dynamic nature of the fatty acid pool in this metabolically active tissue, especially diverting the EFAs towards gametogenesis. Such a specific utilization of EFAs is also in agreement with the suggestions on age- or size-related increases in requirements for essential fatty acids shown in rodents [71-74] and fish [75].

The high correlation found in broodstock males between liver fads 2 expression and Fads2 products or product/precursor ratio was in agreement with the positive correlation between liver fads $2 \mathrm{mRNA}$ expression and 18:3n-6/18:2n-6 ratio found also in rats [76]. Besides, the positive correlation between 20:3n-6 (dihomo- $\gamma$-linolenic acid, DGLA) and ARA with PBCs and/or liver, fads2 expression points out the importance of both fatty acids as precursors of series- 1 and series- 2 prostaglandins, particularly PGE1 and PGE2, which act as precursors and are involved in cell signaling, hormone production, and as an anti-inflammatory molecule [67,77-79]. In agreement with our results, peripheral blood FADS2 expression has been shown to have a positive correlation to DGLA fatty acids in humans [80]. Prostaglandins derived from both fatty acids are found to have a positive effect on testosterone production and sperm quality in fish [81-83]. 
In GSB broodstock, fads2 expression in PBCs has been associated with reproductive performance, suggesting that PBCs fads2 expression could be a useful biomarker to be considered for broodstock selection [31-33]. For instance, GSB expressing higher levels of PBCs fads2 produces higher amounts of eggs and larvae, as well as juveniles with an improved utilization of low fish meal and fish oil diets [30-33,43]. Additionally, we have observed (unpublished) that male broodstock showing higher PBCs fads2 expression also have a better sperm quality with increased sperm motility and duration. Peripheral blood mononuclear cell (PBMCs) gene expression has been proposed as a potential biomarker to correlate the expression of the same genes in various tissues that are non-accessible for biopsies to predict health status, physiological condition, stress, disease diagnosis, or nutrient metabolism in human and land animals [35,37,84-87]. In GSB, PBCs have also been studied as a non-invasive tool to assess mitochondrial energy metabolism [39]. However, until now, the possible relationship between liver fads 2 and PBC fads2 expression has not been addressed. Our study demonstrated that PBC fads2 expression is directly related to liver fads2 expression, since the expression in both types of cells is approximately equal in the males and no correlation was found. On the other hand, a clear correlation between PBCs and liver fads 2 expression was found in female GSB broodstock and was highly correlated in females. Therefore, these results confirm that PBC fads2 expression is a relevant non-invasive biomarker to undertake marker-based selection for improved production of EFAs and reproductive performance in fish. Therefore, PBCs fads2 expression may be a good non-invasive indicator to study the role of fads2 in growth, body composition, health, or reproduction, as well as in studies on fatty acid biosynthesis and metabolism in fish and other animals.

\section{Conclusions}

This study aimed to find the relationship between fads2 expression patterns in peripheral blood cells and liver of broodstock gilthead seabream, Sparus aurata, to see the possible use of the fads2 gene as a potential biomarker for the selection of broodstock to undertake breeding programs aiming at improved reproduction, health and nutritional status. We found a highly positive correlation between fads2 expression levels in the PBCs and liver of GSB broodstock. PBC fads2 can be utilized as a valid biomarker for fatty acid metabolism in fish and is applicable to broodstock selection programs. PBC fads2 expression levels have a good potential as a non-invasive method to select animals having increased fatty acid bioconversion capability and a better ability to deal with fish meal and fish oil free diets.

Supplementary Materials: The following are available online at http://www.mdpi.com/2075-1729/10/7/117/s1, Table S1: Hepatic fatty acid composition (\% total fatty acids) of male and female gilthead sea bream broodstock fed a low FM and low FO diet for one month (M1 to M4-Male; F1 to F16-Female).

Author Contributions: Conceived and designed the experiment, M.I., S.F., S.T., and S.K.; Broodstock selection, M.I., S.F., S.T., H.X., and J.M.A.; Diet formulation and preparation, S.F., M.I., and S.K.; Molecular studies, S.F., S.T., M.J.Z., and M.I.; Biochemical studies, S.F. and M.I.; Analyzed the data, S.F., M.I., and S.K.; Wrote the paper, S.F., M.I., and S.K. All authors have read and agreed to the published version of the manuscript.

Funding: This research received no external funding.

Acknowledgments: This project has received funding from the European Union's Horizon 2020 research, innovation program under grant agreement No 727610 (PerformFISH project). This output reflects the views only of the authors, and the European Union cannot be held responsible for any use which may be made of the information contained therein. The first author gratefully acknowledges the financial assistance provided by the Indian Council of Agricultural Research (ICAR), New Delhi, India and study leave by the Director, ICAR-Central Institute of Freshwater Aquaculture, Bhubaneswar, India for the doctoral study.

Conflicts of Interest: Authors declare no conflict of interest. The funders had no role in the design of the study, analyses, or interpretation of data or writing of the manuscript, or in the decision to publish the manuscripts. 


\section{Abbreviations}

$\begin{array}{ll}\text { ALA } & \text { linolenic acid (18:3n-3) } \\ \text { ARA } & \text { arachidonic acid (20:4n-6) } \\ \text { ddPCR } & \text { droplet digital polymerase chain reaction } \\ \text { DHA } & \text { docosahexaenoic acid (22:6n-3) } \\ \text { EPA } & \text { eicosapentaenoic acid (20:5n-3) } \\ \text { fads2 } & \text { fatty acyl desaturase 2 (gene in fish) } \\ \text { FADS } & \text { fatty acyl desaturase (enzyme in mammals) } \\ \text { Fads } & \text { fatty acyl desaturase (enzyme in fish) } \\ \text { FM } & \text { fish meal } \\ \text { FO } & \text { fish oil } \\ \text { GSB } & \text { gilthead seabream } \\ \text { HD } & \text { high fads2 expression } \\ \text { LA } & \text { linoleic acid (18:2n-6) } \\ \text { LC-PUFA } & \text { long chain polyunsaturated fatty acid } \\ \text { LD } & \text { low fads2 expression } \\ \text { PBCs } & \text { peripheral blood cells } \\ \text { TFA } & \text { total fatty acids }\end{array}$

\section{References}

1. Monroig, O.; Li, Y.; Tocher, D.R. Delta-8 desaturation activity varies among fatty acyl desaturases of teleost fish: High activity in delta-6 desaturases of marine species. Comp. Biochem. Physiol. B 2011, 159, $206-213$. [CrossRef] [PubMed]

2. Monroig, Ó.; Zheng, X.; Morais, S.; Leaver, M.J.; Taggart, J.B.; Tocher, D.R. Multiple genes for functional $\Delta 6$ fatty acyl desaturases (Fad) in Atlantic salmon (Salmo salar L.): Gene and cDNA characterization, functional expression, tissue distribution and nutritional regulation. Biochim. Et Biophys. Acta (BBA)—Mol. Cell Biol. Lipids 2010, 1801, 1072-1081. [CrossRef] [PubMed]

3. Oboh, A.; Kabeya, N.; Carmona-Antoñanzas, G.; Castro, L.F.C.; Dick, J.R.; Tocher, D.R.; Monroig, O. Two alternative pathways for docosahexaenoic acid (DHA, 22:6n-3) biosynthesis are widespread among teleost fish. Sci. Rep. 2017, 7, 1-10. [CrossRef] [PubMed]

4. Tocher, D.R. Omega-3 long-chain polyunsaturated fatty acids and aquaculture in perspective. Aquaculture 2015, 449, 94-107. [CrossRef]

5. Tocher, D.R.; Betancor, M.B.; Sprague, M.; Olsen, R.E.; Napier, J.A. Omega-3 long-chain polyunsaturated fatty acids, EPA and DHA: Bridging the gap between supply and demand. Nutrients 2019, 11, 89. [CrossRef]

6. Castro, L.F.C.; Tocher, D.R.; Monroig, O. Long-chain polyunsaturated fatty acid biosynthesis in chordates: Insights into the evolution of Fads and Elovl gene repertoire. Prog. Lipid Res. 2016, 62, 25-40. [CrossRef]

7. Rivers, J.P.W.; Hassam, A.G.; Crawford, M.A.; Brambell, M.R. The inability of the lion, Panthera leo L. To desaturate linoleic acid. FEBS Lett. 1976, 67, 269-270. [CrossRef]

8. Li, Y.; Monroig, O.; Zhang, L.; Wang, S.; Zheng, X.; Dick, J.R.; You, C.; Tocher, D.R. Vertebrate fatty acyl desaturase with $\triangle 4$ activity. Proc. Natl. Acad. Sci. USA 2010, 107, 16840-16845. [CrossRef]

9. Sprecher, H. Metabolism of highly unsaturated n-3 and n-6 fatty acids. Biochim. Et Biophys. Acta 2000, 1486, 219-231. [CrossRef]

10. Kanazawa, A.; Teshima, S.-I.; Ono, K. Relationship between essential fatty acid requirements of aquatic animals and the capacity for bioconversion of linolenic acid to highly unsaturated fatty acids. Comp. Biochem. Physiol. Part B Comp. Biochem. 1979, 63, 295-298. [CrossRef]

11. Castro, L.F.C.; Monroig, Ó.; Leaver, M.J.; Wilson, J.; Cunha, I.; Tocher, D.R. Functional Desaturase Fads1 ( $\Delta 5)$ and Fads2 ( $\triangle 6)$ Orthologues Evolved before the Origin of Jawed Vertebrates. PLoS ONE 2012, 7, e31950. [CrossRef]

12. Geay, F.; Zambonino-Infante, J.; Reinhardt, R.; Kuhl, H.; Santigosa, E.; Cahu, C.; Mazurais, D. Characteristics of fads2 gene expression and putative promoter in European sea bass (Dicentrarchus labrax): Comparison with salmonid species and analysis of CpG methylation. Mar. Genom. 2012, 5, 7-13. [CrossRef] [PubMed] 
13. Zheng, X.; Leaver, M.J.; Tocher, D.R. Long-chain polyunsaturated fatty acid synthesis in fish: Comparative analysis of Atlantic salmon (Salmo salar L.) and Atlantic cod (Gadus morhua L.) $\Delta 6$ fatty acyl desaturase gene promoters. Comp. Biochem. Physiol.—B Biochem. Mol. Biol. 2009, 154, 255-263. [CrossRef] [PubMed]

14. Kabeya, N.; Fonseca, M.M.; Ferrier, D.E.K.; Navarro, J.C.; Bay, L.K.; Francis, D.S.; Tocher, D.R.; Castro, L.F.C.; Monroig, Ó. Genes for de novo biosynthesis of omega-3 polyunsaturated fatty acids are widespread in animals. Sci. Adv. 2018, 4, 1-8. [CrossRef] [PubMed]

15. Park, H.G.; Park, W.J.; Kothapalli, K.S.D.; Brenna, J.T. The fatty acid desaturase 2 (FADS2) gene product catalyzes $\triangle 4$ desaturation to yield n-3 docosahexaenoic acid and n-6 docosapentaenoic acid in human cells. FASEB J. 2015, 29, 3911-3919. [CrossRef]

16. Hastings, N.; Agaba, M.; Tocher, D.R.; Leaver, M.J.; Dick, J.R.; Sargent, J.R.; Teale, A.J. A vertebrate fatty acid desaturase with $\Delta 5$ and $\Delta 6$ activities. Proc. Natl. Acad. Sci. USA 2001, 98, 14304-14309. [CrossRef]

17. Izquierdo, M.; Robaina, L.; Juárez-Carrillo, E.; Oliva, V.; Hernández-Cruz, C.M.; Afonso, J.M. Regulation of growth, fatty acid composition and delta 6 desaturase expression by dietary lipids in gilthead seabream larvae (Sparus aurata). Fish Physiol. Biochem. 2008, 34, 117-127. [CrossRef]

18. Seiliez, I.; Panserat, S.; Corraze, G.; Kaushik, S.; Bergot, P. Cloning and nutritional regulation of a $\Delta 6$-desaturase-like enzyme in the marine teleost gilthead seabream (Sparus aurata). Comp. Biochem. Physiol. Part B: Biochem. Mol. Biol. 2003, 135, 449-460. [CrossRef]

19. Zheng, X.; Seiliez, I.; Hastings, N.; Tocher, D.R.; Panserat, S.; Dickson, C.A.; Bergot, P.; Teale, A.J. Characterization and comparison of fatty acyl $\Delta 6$ desaturase cDNAs from freshwater and marine teleost fish species. Comp. Biochem. Physiol. B 2004, 139, 269-279. [CrossRef]

20. Vagner, M.; Santigosa, E. Characterization and modulation of gene expression and enzymatic activity of delta-6 desaturase in teleosts: A review. Aquaculture 2011, 315, 131-143. [CrossRef]

21. González-Rovira, A.; Mourente, G.; Zheng, X.; Tocher, D.R.; Pendón, C. Molecular and functional characterization and expression analysis of a $\Delta 6$ fatty acyl desaturase cDNA of European Sea Bass (Dicentrarchus labrax L.). Aquaculture 2009, 298, 90-100. [CrossRef]

22. Santigosa, E.; Geay, F.; Tonon, T.; Delliou, H.L.; Kuhl, H.; Reinhardt, R.; Corcos, L.; Cahu, C.; Zambonino-Infante, J.L.; Mazurais, D. Cloning, Tissue Expression Analysis, and Functional Characterization of Two $\Delta 6$-Desaturase Variants of Sea Bass (Dicentrarchus labrax L.). Mar. Biotechnol. 2011, 13, $22-31$. [CrossRef] [PubMed]

23. Kim, S.H.; Kim, J.B.; Kim, S.Y.; Roh, K.H.; Kim, H.U.; Lee, K.R.; Jang, Y.S.; Kwon, M.; Park, J.S. Functional characterization of a delta 6-desaturase gene from the black seabream (Acanthopagrus schlegeli). Biotechnol. Lett. 2011, 33, 1185-1193. [CrossRef] [PubMed]

24. Monroig, Ó.; Tocher, D.R.; Hontoria, F.; Navarro, J.C. Functional characterisation of a Fads2 fatty acyl desaturase with $\Delta 6 / \Delta 8$ activity and an Elovl5 with $C 16, C 18$ and $C 20$ elongase activity in the anadromous teleost meagre (Argyrosomus regius). Aquaculture 2013, 412-413, 14-22. [CrossRef]

25. Li, S.; Mai, K.; Xu, W.; Yuan, Y.; Zhang, Y.; Ai, Q. Characterization, mRNA expression and regulation of $\Delta 6$ fatty acyl desaturase (FADS2) by dietary $n-3$ long chain polyunsaturated fatty acid (LC-PUFA) levels in grouper larvae (Epinephelus coioides). Aquaculture 2014, 434, 212-219. [CrossRef]

26. Kabeya, N.; Yamamoto, Y.; Cummins, S.F.; Elizur, A.; Yazawa, R.; Takeuchi, Y.; Haga, Y.; Satoh, S.; Yoshizaki, G. Polyunsaturated fatty acid metabolism in a marine teleost, Nibe croaker Nibea mitsukurii: Functional characterization of Fads2 desaturase and Elovl5 and Elovl4 elongases. Comp. Biochem. Physiol. Part-B Biochem. Mol. Biol. 2015, 188, 37-45. [CrossRef]

27. Lim, Z.L.; Senger, T.; Vrinten, P. Four amino acid residues influence the substrate chain-length and regioselectivity of siganus canaliculatus $\delta 4$ and $\delta 5 / 6$ desaturases. Lipids 2014, 49, 357-367. [CrossRef]

28. Zheng, X.; Tocher, D.R.; Dickson, C.A.; Bell, J.G.; Teale, A.J. Highly unsaturated fatty acid synthesis in vertebrates: New insights with the cloning and characterization of a $\Delta 6$ desaturase of atlantic salmon. Lipids 2005, 40, 13-24. [CrossRef]

29. Tocher, D.R.; Zheng, X.; Schlechtriem, C.; Hastings, N.; Dick, J.R.; Teale, A.J. Highly unsaturated fatty acid synthesis in marine fish: Cloning, functional characterization, and nutritional regulation of fatty acyl $\Delta 6$ desaturase of Atlantic cod (Gadus morhua L.). Lipids 2006, 41, 1003-1016. [CrossRef]

30. Izquierdo, M.S.; Turkmen, S.; Montero, D.; Zamorano, M.J.; Afonso, J.M.; Karalazos, V.; Fernández-Palacios, H. Nutritional programming through broodstock diets to improve utilization of very low fishmeal and fish oil diets in gilthead sea bream. Aquaculture 2015, 449, 18-26. [CrossRef] 
31. Turkmen, S.; Perera, E.; Zamorano, M.J.; Simó-Mirabet, P.; Xu, H.; Pérez-Sánchez, J.; Izquierdo, M. Effects of Dietary Lipid Composition and Fatty Acid Desaturase 2 Expression in Broodstock Gilthead Sea Bream on Lipid Metabolism-Related Genes and Methylation of the fads2 Gene Promoter in Their Offspring. Int. J. Mol. Sci. 2019, 20, 6250. [CrossRef] [PubMed]

32. Turkmen, S.; Zamorano, M.J.; Fernández-Palacios, H.; Hernández-Cruz, C.M.; Montero, D.; Robaina, L.; Izquierdo, M. Parental nutritional programming and a reminder during juvenile stage affect growth, lipid metabolism and utilisation in later developmental stages of a marine teleost, the gilthead sea bream (Sparus aurata). Br. J. Nutr. 2017, 118, 500-512. [CrossRef]

33. Xu, H.; Turkmen, S.; Rimoldi, S.; Terova, G.; Zamorano, M.J.; Afonso, J.M.; Sarih, S.; Fernández-Palacios, H.; Izquierdo, M. Nutritional intervention through dietary vegetable proteins and lipids to gilthead sea bream (Sparus aurata) broodstock affects the offspring utilization of a low fishmeal/fish oil diet. Aquaculture 2019, 513, 734402. [CrossRef]

34. Tocher, D.R. Metabolism and functions of lipids and fatty acids in teleost fish. Rev. Fish. Sci. 2003, 11, 107-184. [CrossRef]

35. Halloran, J.W.; Zhu, D.; Qian, D.C.; Byun, J.; Gorlova, O.Y.; Amos, C.I.; Gorlov, I.P. Prediction of the gene expression in normal lung tissue by the gene expression in blood. BMC Med Genom. 2015, 8, 1-6. [CrossRef] [PubMed]

36. Hasan, F.; Yadav, V.; Katiyar, T.; Yadav, S.; Pandey, R.; Mehrotra, D.; Hadi, R.; Singh, S.; Bhatt, M.L.B.; Parmar, D. Validation of gene expression profiles of candidate genes using low density array in peripheral blood of tobacco consuming head and neck cancer patients and auto/taxi drivers with preneoplastic lesions. Genomics 2020, 112, 513-519. [CrossRef] [PubMed]

37. Liew, C.C.; Ma, J.; Tang, H.C.; Zheng, R.; Dempsey, A.A. The peripheral blood transcriptome dynamically reflects system wide biology: A potential diagnostic tool. J. Lab. Clin. Med. 2006, 147, 126-132. [CrossRef]

38. Palmer, N.P.; Silvester, J.A.; Lee, J.J.; Beam, A.L.; Fried, I.; Valtchinov, V.I.; Rahimov, F.; Kong, S.W.; Ghodoussipour, S.; Hood, H.C.; et al. Concordance between gene expression in peripheral whole blood and colonic tissue in children with inflammatory bowel disease. PLoS ONE 2019, 14, 1-14. [CrossRef]

39. Martos-Sitcha, J.A.; Simó-Mirabet, P.; de las Heras, V.; Calduch-Giner, J.À.; Pérez-Sánchez, J. Tissue-Specific Orchestration of Gilthead Sea Bream Resilience to Hypoxia and High Stocking Density. Front. Physiol. 2019, 10, 1-18. [CrossRef]

40. Reynolds, L.M.; Howard, T.D.; Ruczinski, I.; Kanchan, K.; Seeds, M.C.; Mathias, R.A.; Chilton, F.H. Tissue-specific impact of FADS cluster variants on FADS1 and FADS2 gene expression. PLoS ONE 2018, 13, e0194610. [CrossRef]

41. Xu, H.; Dong, X.; Ai, Q.; Mai, K.; Xu, W.; Zhang, Y.; Zuo, R. Regulation of Tissue LC-PUFA Contents, $\Delta 6$ Fatty Acyl Desaturase (FADS2) Gene Expression and the Methylation of the Putative FADS2 Gene Promoter by Different Dietary Fatty Acid Profiles in Japanese Seabass (Lateolabrax japonicus). PLoS ONE 2014, 9, e87726. [CrossRef] [PubMed]

42. Zhu, K.C.; Song, L.; Guo, H.Y.; Guo, L.; Zhang, N.; Liu, B.S.; Jiang, S.G.; Zhang, D.C. Identification of fatty acid desaturase 6 in golden pompano Trachinotus ovatus (Linnaeus 1758) and its regulation by the PPAR $\alpha \mathrm{b}$ transcription factor. Int. J. Mol. Sci. 2019, 20, 23. [CrossRef] [PubMed]

43. Turkmen, S.; Hernández-Cruz, C.M.; Zamorano, M.J.; Fernández-Palacios, H.; Montero, D.; Afonso, J.M.; Izquierdo, M. Long-chain PUFA profiles in parental diets induce long-term effects on growth, fatty acid profiles, expression of fatty acid desaturase 2 and selected immune system-related genes in the offspring of gilthead seabream. Br. J. Nutr. 2019, 122, 25-38. [CrossRef] [PubMed]

44. Bakewell, L.; Burdge, G.C.; Calder, P.C. Polyunsaturated fatty acid concentrations in young men and women consuming their habitual diets. Br. J. Nutr. 2006, 96, 93. [CrossRef]

45. Childs, C.E.; Hoile, S.P.; Burdge, G.C.; Calder, P.C. Changes in rat n-3 and n-6 fatty acid composition during pregnancy are associated with progesterone concentrations and hepatic FADS2 expression. Prostaglandins Leukot. Essent. Fat. Acids 2012, 86, 141-147. [CrossRef] [PubMed]

46. Childs, C.E.; Romeu-Nadal, M.; Burdge, G.C.; Calder, P.C. The Polyunsaturated Fatty Acid Composition of Hepatic and Plasma Lipids Differ by Both Sex and Dietary Fat Intake in Rats. J. Nutr. 2010, 140, $245-250$. [CrossRef] 
47. Childs, C.E.; Romijn, T.; Enke, U.; Hoile, S.; Calder, P.C. Maternal diet during pregnancy has tissue-specific effects upon fetal fatty acid composition and alters fetal immune parameters. Prostaglandins Leukot. Essent. Fat. Acids 2010, 83, 179-184. [CrossRef]

48. Torrecillas, S.; Robaina, L.; Caballero, M.J.; Montero, D.; Calandra, G.; Mompel, D.; Karalazos, V.; Kaushik, S.; Izquierdo, M.S. Combined replacement of fishmeal and fish oil in European sea bass (Dicentrarchus labrax): Production performance, tissue composition and liver morphology. Aquaculture 2017, 474, 101-112. [CrossRef]

49. Folch, J.; Lees, M.; Stanley, G.S. A simple method for the isolation and purification of total lipides from animal tissues. J. Biol. Chem. 1957, 226, 497-509.

50. Christie, W.W. A simple procedure for rapid transmethylation of glycerolipids and cholesteryl esters. J. Lipid Res. 1982, 23, 1072-1075.

51. Izquierdo, M.S.; Watanabe, T.; Takeuchi, T.; Arakawa, T.; Kitajima, C. Optimum EFA levels in Artemia to meet the EFA requirements of red sea bream (Pagrus major). In Proceedings of the Third International Symposium on Feeding and Nutrition in Fish, Toba, Japan, 28 August-1 September 1990; pp. 221-232.

52. Hoile, S.P.; Irvine, N.A.; Kelsall, C.J.; Sibbons, C.; Feunteun, A.; Collister, A.; Torrens, C.; Calder, P.C.; Hanson, M.A.; Lillycrop, K.A.; et al. Maternal fat intake in rats alters 20:4n-6 and 22:6n-3 status and the epigenetic regulation of Fads2 in offspring liver. J. Nutr. Biochem. 2013, 24, 1213-1220. [CrossRef] [PubMed]

53. Niculescu, M.D.; Lupu, D.S.; Craciunescu, C.N. Perinatal manipulation of $\alpha$-linolenic acid intake induces epigenetic changes in maternal and offspring livers. FASEB J. 2013, 27, 350-358. [CrossRef] [PubMed]

54. Burdge, G.C.; Calder, P.C. Conversion of $\alpha$-linolenic acid to longer-chain polyunsaturated fatty acids in human adults. Reprod. Nutr. Dev. 2005, 45, 581-597. [CrossRef]

55. Chalil, A.; Kitson, A.P.; Henao, J.J.A.; Marks, K.A.; Elzinga, J.L.; Lamontagne-Kam, D.M.; Chalil, D.; Badoud, F.; Mutch, D.M.; Stark, K.D. PEMT, $\Delta 6$ desaturase, and palmitoyldocosahexaenoyl phosphatidylcholine are increased in rats during pregnancy. J. Lipid Res. 2018, 59, 123-136. [CrossRef] [PubMed]

56. Kitson, A.P.; Marks, K.A.; Shaw, B.; Mutch, D.M.; Stark, K.D. Treatment of ovariectomized rats with $17 \beta$-estradiol increases hepatic delta-6 desaturase enzyme expression and docosahexaenoic acid levels in hepatic and plasma phospholipids. ProstaglandinsLeukot. Essent. Fat. Acids 2013, 89, 81-88. [CrossRef] [PubMed]

57. Arukwe, A.; Goksøyr, A. Eggshell and egg yolk proteins in fish: Hepatic proteins for the next generation: Oogenetic, population, and evolutionary implications of endocrine disruption. Comp. Hepatol. 2003, 2, 4. [CrossRef] [PubMed]

58. Chaoui, L.; Kara, M.H.; Faure, E.; Quignard, J.P. Growth and reproduction of the gilthead seabream Sparus aurata in Mellah lagoon (north-eastern Algeria). Sci. Mar. 2006, 70, 545-552. [CrossRef]

59. Kissil, G.W.; Lupatsch, I.; Elizur, A.; Zohar, Y. Long photoperiod delayed spawning and increased somatic growth in gilthead seabream (Sparus aurata). Aquaculture 2001, 200, 363-379. [CrossRef]

60. Zohar, Y.; Abraham, M.; Gordin, H. The gonadal cycle of the captivity-reared hermaphroditic teleost Sparus aurata (L.) during the first two years of life. Ann. De Biol. Anim. Biochim. Biophys. 1978, 18, 877-882. [CrossRef]

61. Houston, S.J.; Karalazos, V.; Tinsley, J.; Betancor, M.B.; Martin, S.A.; Tocher, D.R.; Monroig, O. The compositional and metabolic responses of gilthead seabream (Sparus aurata) to a gradient of dietary fish oil and associated n-3 long-chain PUFA content. Br. J. Nutr. 2017, 118, 1010-1022. [CrossRef]

62. Fernández-Palacios, H.; Izquierdo, M.S.; Robaina, L.; Valencia, A.; Salhi, M.; Vergara, J.M. Effect of n-3 HUFA level in broodstock diets on egg quality of gilthead sea bream (Sparus aurata L.). Aquaculture 1995, 132, 325-338.

63. Harel, M.; Tandler, A.; Kissil, G.W.; Applebaum, S.W. The kinetics of nutrient incorporation into body tissues of gilthead seabream (Sparus aurata) females and the subsequent effects on egg composition and egg quality. Br. J. Nutr. 1994, 72, 45-58. [CrossRef] [PubMed]

64. Izquierdo, M.S. Essential fatty acid requirements of cultured marine fish larvae. Aquac. Nutr. 1996, 2, $183-191$. [CrossRef]

65. Izquierdo, M.S.; Fernández-Palacios, H.; Tacon, A.G.J. Effect of broodstock nutrition on reproductive performance of fish. Aquaculture 2001, 197, 25-42. [CrossRef] 
66. Mazorra, C.; Bruce, M.; Bell, J.G.; Davie, A.; Alorend, E.; Jordan, N.; Rees, J.; Papanikos, N.; Porter, M.; Bromage, N. Dietary lipid enhancement of broodstock reproductive performance and egg and larval quality in Atlantic halibut (Hippoglossus hippoglossus). Aquaculture 2003, 227, 21-33. [CrossRef]

67. Stacey, N.; Goetz, F.W. Role of prostaglandins in fish reproduction. Can. J. Fish. Aquat. Sci. 1982, 39, 92-98. [CrossRef]

68. Chaves-Pozo, E.; Arjona, F.; García-López, A.; García-Alcázar, A.; Meseguer, J.; García-Ayala, A. Sex steroids and metabolic parameter levels in a seasonal breeding fish (Sparus aurata L.). Gen. Comp. Endocrinol. 2008, 156, 531-536. [CrossRef]

69. Firat, K.; Saka, Ş.; Süzer, C. Gonadal oocyte development in LHRHa hormone treated European sea bass (Dicentrarchus labrax L., 1758) Broodstock. Turk. J. Vet. Anim. Sci. 2005, 29, 83-87.

70. Migaud, H.; Bell, G.; Cabrita, E.; McAndrew, B.; Davie, A.; Bobe, J.; Herraez, M.P.; Carrillo, M. Gamete quality and broodstock management in temperate fish. Rev. Aquac. 2013, 5, S194-S223. [CrossRef]

71. Chapman, C.; Morgan, L.M.; Murphy, M.C. Maternal and early dietary fatty acid intake: Changes in lipid metabolism and liver enzymes in adult rats. J. Nutr. 2000, 130, 146-151. [CrossRef]

72. Dupont, J.; Mathias, M.M.; Cabacungan, N.B. Dietary lipid, fatty acid synthesis and cholesterol metabolism in aging rats. Lipids 1972, 7, 576-589. [CrossRef] [PubMed]

73. Hood, R. Changes in fatty acid synthesis associated with growth and fattening. Proc. Nutr. Soc. 1983, 42, 303-313. [CrossRef] [PubMed]

74. Nogalska, A.; Swierczynski, J. The age-related differences in obese and fatty acid synthase gene expression in white adipose tissue of rat. Biochim. Et Biophys. Acta (BBA)-Mol. Cell Biol. Lipids 2001, 1533, 73-80. [CrossRef]

75. Izquierdo, M.; Montero, D.; Robaina, L.; Caballero, M.; Rosenlund, G.; Ginés, R. Alterations in fillet fatty acid profile and flesh quality in gilthead seabream (Sparus aurata) fed vegetable oils for a long term period. Recovery of fatty acid profiles by fish oil feeding. Aquaculture 2005, 250, 431-444. [CrossRef]

76. Hofacer, R.; Jandacek, R.; Rider, T.; Tso, P.; Magrisso, I.J.; Benoit, S.C.; McNamara, R.K. Omega-3 fatty acid deficiency selectively up-regulates delta6-desaturase expression and activity indices in rat liver: Prevention by normalization of omega-3 fatty acid status. Nutr. Res. 2011, 31, 715-722. [CrossRef] [PubMed]

77. Abayasekara, D.; Wathes, D. Effects of altering dietary fatty acid composition on prostaglandin synthesis and fertility. ProstaglandinsLeukot. Essent. Fat. Acids (PLEFA) 1999, 61, 275-287. [CrossRef] [PubMed]

78. Cheng, Z.; Elmes, M.; Kirkup, S.; Abayasekara, D.; Wathes, D. Effects of n-6 polyunsaturated fatty acids on prostaglandin production in ovine fetal chorion cells in vitro in late gestation ewes. Placenta 2011, 32, 752-756. [CrossRef] [PubMed]

79. Ganga, R.; Tort, L.; Acerete, L.; Montero, D.; Izquierdo, M. Modulation of ACTH-induced cortisol release by polyunsaturated fatty acids in interrenal cells from gilthead seabream, Sparus aurata. J. Endocrinol. 2006, 190, 39-45. [CrossRef] [PubMed]

80. Chisaguano, A.M.; Montes, R.; Pérez-Berezo, T.; Castellote, A.I.; Guerendiain, M.; Bustamante, M.; Morales, E.; García-Esteban, R.; Sunyer, J.; Franch, À. Gene expression of desaturase (FADS1 and FADS2) and Elongase (ELOVL5) enzymes in peripheral blood: Association with polyunsaturated fatty acid levels and atopic eczema in 4-year-old children. PLoS ONE 2013, 8, e78245. [CrossRef]

81. Asturiano, J.; Sorbera, L.; Carrillo, M.; Zanuy, S.; Ramos, J.; Navarro, J.; Bromage, N. Reproductive performance in male European sea bass (Dicentrarchus labrax, L.) fed two PUFA-enriched experimental diets: A comparison with males fed a wet diet. Aquaculture 2001, 194, 173-190. [CrossRef]

82. Asturiano, J.; Sorbera, L.; Zanuy, S.; Carrillo, M. Effects of polyunsaturated fatty acids and gonadotropin on prostaglandin series E production in a primary testis cell culture system for the European sea bass. J. Fish Biol. 2000, 57, 1563-1574. [CrossRef]

83. Wade, M.G.; Van Der Kraak, G. Arachidonic acid and prostaglandin E2 stimulate testosterone production by goldfish testis in vitro. Gen. Comp. Endocrinol. 1993, 90, 109-118. [CrossRef] [PubMed]

84. Bouwens, M.; Afman, L.A.; Müller, M. Fasting induces changes in peripheral blood mononuclear cell gene expression profiles related to increases in fatty acid $\beta$-oxidation: Functional role of peroxisome proliferator-activated receptor $\alpha$ in human peripheral blood mononuclear cells. Am. J. Clin. Nutr. 2007, 86, 1515-1523. [CrossRef] [PubMed]

85. Caimari, A.; Oliver, P.; Keijer, J.; Palou, A. Peripheral Blood Mononuclear Cells as a Model to Study the Response of Energy Homeostasis-Related Genes to Acute Changes in Feeding Conditions. Omics A J. Integr. Biol. 2010, 14, 129-141. [CrossRef] 
86. Caimari, A.; Oliver, P.; Rodenburg, W.; Keijer, J.; Palou, A. Slc27a2 expression in peripheral blood mononuclear cells as a molecular marker for overweight development. Int. J. Obes. 2010, 34, 831-839. [CrossRef]

87. de Mello, V.D.F.; Kolehmanien, M.; Schwab, U.; Pulkkinen, L.; Uusitupa, M. Gene expression of peripheral blood mononuclear cells as a tool in dietary intervention studies: What do we know so far? Mol. Nutr. Food Res. 2012, 56, 1160-1172. [CrossRef]

(C) 2020 by the authors. Licensee MDPI, Basel, Switzerland. This article is an open access article distributed under the terms and conditions of the Creative Commons Attribution (CC BY) license (http://creativecommons.org/licenses/by/4.0/). 